\title{
Defense Programs Beryllium Good Practice Guide
}

\author{
Monty Herr
}

July 1997

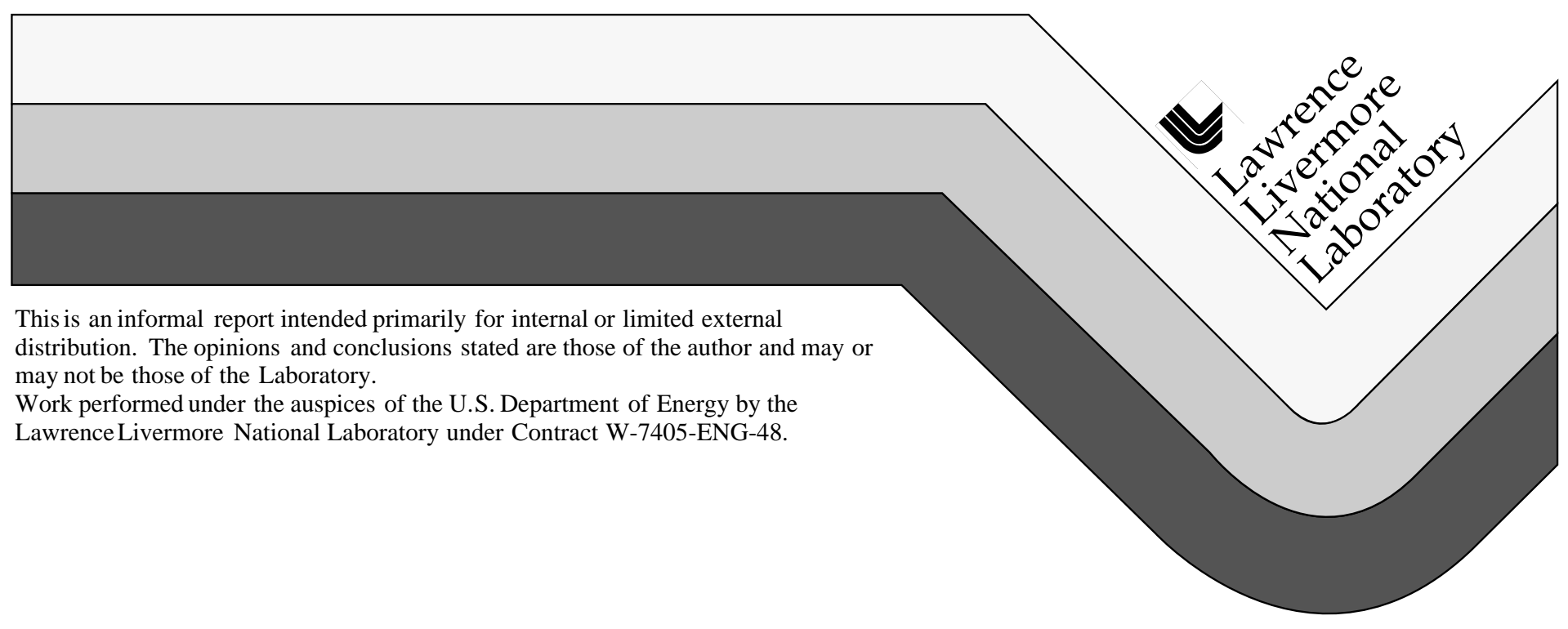




\section{DISCLAIMER}

This document was prepared as an account of work sponsored by an agency of the United States Government. Neither the United States Government nor the University of California nor any of their employees, makes any warranty, express or implied, or assumes any legal liability or responsibility for the accuracy, completeness, or usefulness of any information, apparatus, product, or process disclosed, or represents that its use would not infringe privately owned rights. Reference herein to any specific commercial product, process, or service by trade name, trademark, manufacturer, or otherwise, does not necessarily constitute or imply its endorsement, recommendation, or favoring by the United States Government or the University of California. The views and opinions of authors expressed herein do not necessarily state or reflect those of the United States Government or the University of California, and shall not be used for advertising or product endorsement purposes.

This report has been reproduced directly from the best available copy.

Available to DOE and DOE contractors from the Office of Scientific and Technical Information

P.O. Box 62, Oak Ridge, TN 37831

Prices available from (615) 576-8401, FTS 626-8401

Available to the public from the

National Technical Information Service

U.S. Department of Commerce 5285 Port Royal Rd.,

Springfield, VA 22161 


\section{Defense Programs \\ Beryllium Good Practice Guide}

\section{Contents}

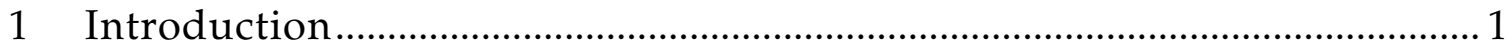

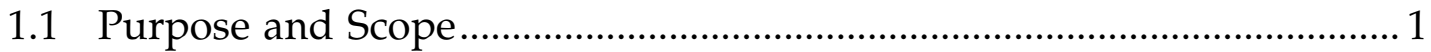

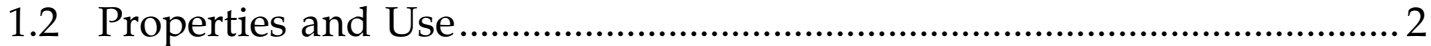

2 Toxicology and Biological Effects of Beryllium................................................ 3

2.1 Extent of Exposure ……………............................................................. 3

2.2 Effects on Humans.............................................................................. 4

2.2.1 Acute Beryllium Disease............................................................... 4

2.2.2 Chronic Beryllium Disease.............................................................. 4

2.2.3 Lung Cancer ................................................................................. 5

2.3 Historical Aspects..................................................................................5

2.3.1 Acute Beryllium Disease............................................................. 5

2.3.2 Chronic Beryllium Disease........................................................... 6

2.3.3 Neighborhood Cases ...................................................................... 6

2.4 Animal Models ............................................................................... 6

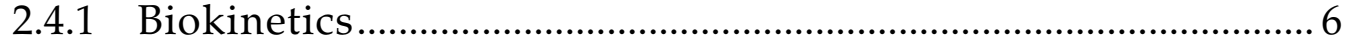

2.4.2 Toxic and Immunological Effects...............................................

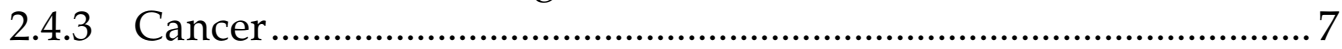

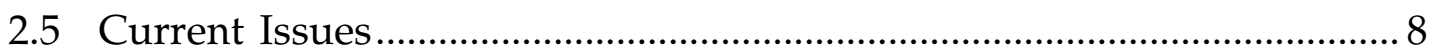

2.5.1 Relationship between Sensitization and Disease ….................... 8

2.5.2 Current Large-scale Screening Programs ......................................... 8

2.5.3 Effect on Physicochemical Form and Frequency of

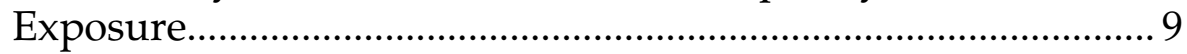

2.5.4 Human Carcinogenicity ............................................................... 9

3 Standards and Regulations....................................................................... 9

3.1 Occupational Limits .............................................................................. 10

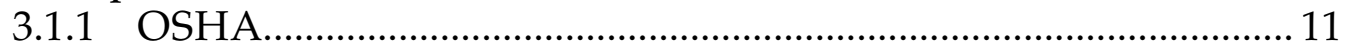

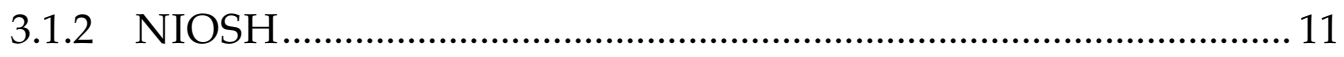

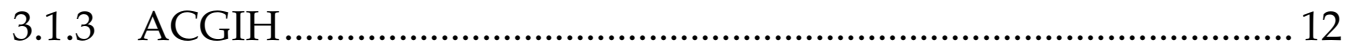

3.2 Environmental Limits.......................................................................... 12

3.2.1 Air Programs................................................................................ 12

3.2.2 Water Programs ............................................................................. 13

3.2.3 Superfund Amendments and Reauthorization Act (SARA) Regulations................................................................ 13

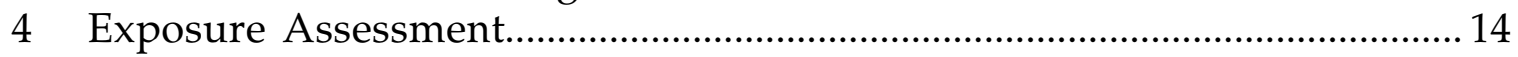

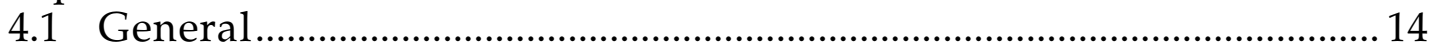

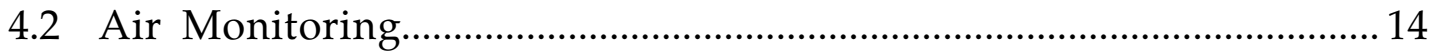

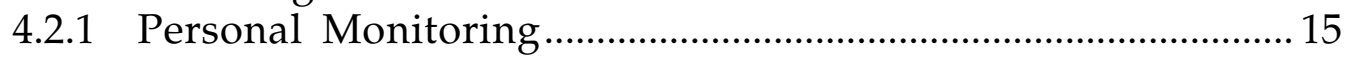

4.2.2 Area Monitoring ....................................................................... 17

4.2.3 Surface Monitoring ...................................................................... 18 
5 Controls for Beryllium Exposure …………….......................................... 19

5.1 Engineering Controls ....................................................................... 20

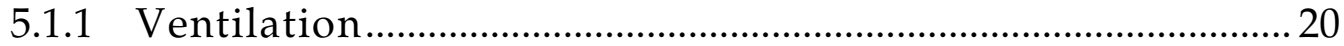

5.1.2 Other Controls............................................................................. 21

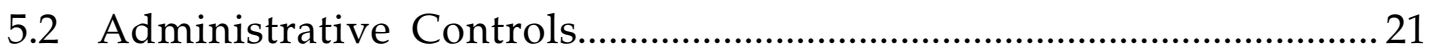

5.2.1 Restricted Access Areas................................................................... 22

5.2.2 Change Rooms and Shower Facilities........................................ 23

5.2.3 Personal Hygiene .......................................................................... 23

5.2.4 Warning Signs and Labels ............................................................. 24

5.2.5 Recordkeeping ............................................................................. 24

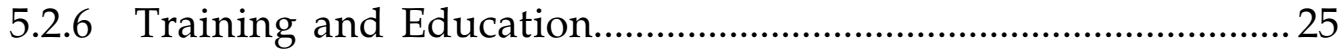

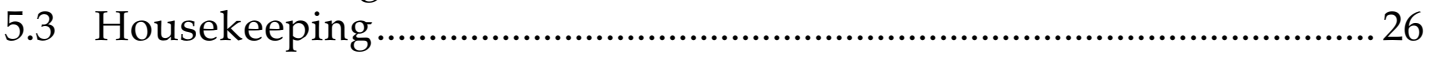

5.4 Personal Protective Equipment .............................................................2 27

5.4.1 Protective Clothing...................................................................... 27

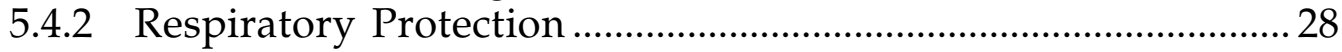

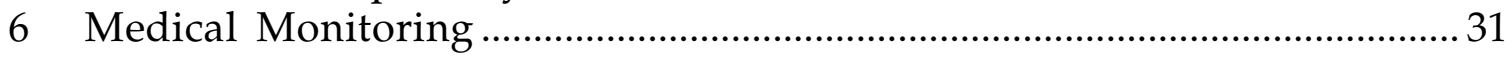

6.1 Medical Surveillance Categorized by Exposure........................................ 31

6.2 Medical Monitoring for CBD.................................................................... 32

6.2.1 High-Exposure Workers............................................................... 32

6.2.2 Low-Exposure Workers................................................................ 33

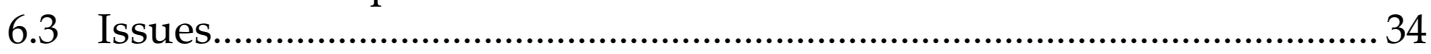

$7 \quad$ Waste Management .............................................................................................. 34

8 Decommissioning and Decontamination Projects.......................................... 34

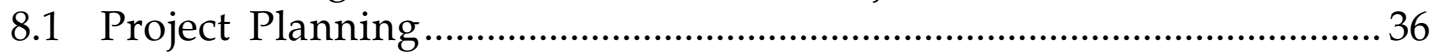

8.2 Protecting Personnel ............................................................................... 37

8.3 Decontamination of Equipment...............................................................38

8.4 Decontamination of Beryllium Facilities..................................................39

8.5 Conclusion of Decontamination Project ………....................................... 40

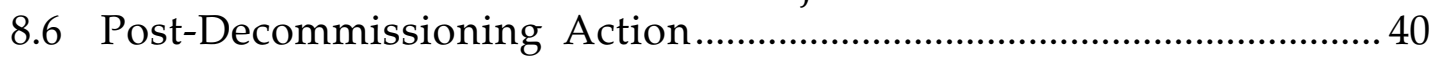

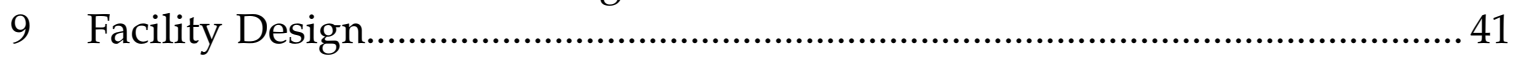

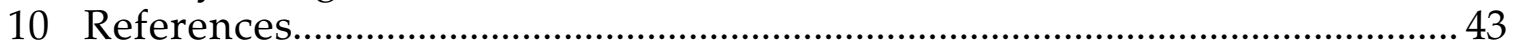

Appendix A Details of EPA Regulation............................................................. 49 


\section{Introduction}

\subsection{Purpose and Scope}

Within the DOE, it has recently become apparent that some contractor employees who have worked (or are currently working) with and around beryllium have developed chronic beryllium disease (CBD), an occupational granulomatous lung disorder. Respiratory exposure to aerosolized beryllium, in susceptible individuals, causes an immunological reaction that can result in granulomatous scarring of the lung parenchyma, shortness of breath, cough, fatigue, weight loss, and, ultimately, respiratory failure.

Beryllium disease was originally identified in the 1940s, largely in the fluorescent light industry. In 1950, the Atomic Energy Commission (AEC) introduced strict exposure standards that generally curtailed both the acute and chronic forms of the disease. Beginning in 1984, with the identification of a CBD case in a DOE contractor worker, there was increased scrutiny of both industrial hygiene practices and individuals in this workforce. To date, over 100 additional cases of beryllium-specific sensitization and/or CBD have been identified. Thus, a disease previously thought to be largely eliminated by the adoption of permissible exposure standards 45 years ago is still a health risk in certain workforces.

This good practice guide forms the basis of an acceptable program for controlling workplace exposure to beryllium. It provides

- Guidance for minimizing worker exposure to beryllium in Defense Programs facilities during all phases of beryllium-related work, including the decontamination and decommissioning (D\&D) of facilities.

- Recommended controls to be applied to the handling of metallic beryllium and beryllium alloys, beryllium oxide, and other beryllium compounds.

- Recommendations for medical monitoring and surveillance of workers exposed (or potentially exposed) to beryllium, based on the best current understanding of beryllium disease and medical diagnostic tests available.

- Site-specific safety procedures for all processes of beryllium that is likely to generate dusts, mists, fumes, or small particulates.

A beryllium exposure control program should minimize

- Airborne concentrations.

- The potential for and spread of contamination.

- The number of times individuals are exposed to beryllium.

- The number of employees who may be potentially exposed. 


\subsection{Properties and Use}

Beryllium is a silver-gray metal that has a low density, moderately high melting point, good stability, and good mechanical properties-particularly specific stiffness, which is six times greater than steel (see Table 1-1). Beryllium is a natural occurring mineral estimated to be present in the earth's surface in concentrations of 1 to $6 \mathrm{ppm}$. There are approximately 45 beryllium-containing minerals. The commercially important minerals include beryl, $3 \mathrm{BeOAl}_{2} \mathrm{O}_{3} \cdot 6 \mathrm{SiO}_{2}$, phenakite, $2 \mathrm{BeO}^{\circ} \mathrm{SiO}_{2}$; bertrandite, $4 \mathrm{BeO}^{2} 2 \mathrm{SiO}_{2} \mathrm{H}_{2} \mathrm{O}$; and chrysoberyl, $\mathrm{BeOAl}_{2} \mathrm{O}_{3}$. Beryl has been known since ancient times as the gemstones emerald (green), aquamarine (light blue), and beryl (yellow). Today, the primary forms of beryllium used are pure metal, metal alloys, and beryllium oxide.

Beryllium is an essential material used in many applications within the Department of Energy (DOE), Department of Defense, and in private industry. It is used in a number of aerospace applications, including major components on satellites and spacecraft. The pure metal is used in high-strength, nonsparking copper alloy tools; as moderators and neutron reflectors in nuclear reactors; as components in nuclear weapons; in light-weight, highperformance aircraft brakes; and in mirrors in satellite optical systems. Because beryllium transmits $\mathrm{x}$-rays 17 times greater than aluminum, it is also used extensively in making windows for x-ray tubes. The high-fired oxide (see Table 1-2) is used as a ceramic in electronic applications and in lasers.

\begin{tabular}{|l|l|}
\hline \multicolumn{2}{|l|}{ Table 1-1. Physical properties of beryllium. } \\
\hline Atomic number & 4 \\
\hline Atomic weight & 9.0122 \\
\hline Density & $1.8477 \mathrm{~g} / \mathrm{cm}^{3}$ \\
\hline Melting point & $1287^{\circ} \mathrm{C}$ \\
\hline Boiling point & $2472^{\circ} \mathrm{C}$ \\
\hline
\end{tabular}

\begin{tabular}{|l|l|}
\hline \multicolumn{2}{|l|}{ Table 1-2. Physical properties of beryllium oxide. } \\
\hline Formula & $\mathrm{BeO}$ \\
\hline Molecular weight & 25.01 \\
\hline Density & $3.01 \mathrm{~g} / \mathrm{cm}^{3}$ \\
\hline Melting point & $\mathrm{ca} 2530^{\circ} \mathrm{C}$ \\
\hline Boiling point & $\mathrm{ca} 3900^{\circ} \mathrm{C}$ \\
\hline
\end{tabular}


Beryllium alloyed with copper, aluminum, and other metals is a popular engineering material in the electronics, automotive, defense, and aerospace industries. Beryllium-oxide powder formed into shapes by processes such as dry pressing and extruding and subsequent firing produces a ceramic with an exceptional combination of high thermal conductivity, high electrical resistivity, and excellent dielectric properties. The ceramic is used in a number of electronics, laser, automotive, and defense applications.

While a number of DOE facilities have used beryllium over the years, a few still use it today in operations such as

1. Fabrication of beryllium metal components for nuclear weapons. These operations consist principally of machining beryllium metal pieces purchased from a vendor. The finished pieces are handled by workers involved in quality assurance and assembly activities.

2. Fabrication of beryllium oxide ceramic components for nuclear weapons. The principal operation consists of diamond grinding, high-precision machining of ceramic pieces that are primarily purchased from a vendor.

3. Ceramic hot press where beryllium oxide powder is mixed with other compounds, pressed into the desired shape, and fired in a kiln.

4. Destructive testing operations associated with development of new devices in which beryllium components are included in a nonnuclear package that is destroyed using high explosives.

5. Weapons assembly and disassembly, where workers receive, handle, and store beryllium parts.

6. Beryllium alloy and process development.

\section{Toxicology and Biological Effects of Beryllium}

The toxicity of beryllium became apparent in the 1930s, but has only been generally recognized since the 1940s. This section provides a general review of the toxicity of beryllium to humans and experimental animals, and describes the characteristics of beryllium-related diseases and current issues. A more thorough review of the toxicology of beryllium can be found in several recent reviews (Meyer 1994; IARC 1993; Rossman, Preuss, and Powers 1991; Kriebel 1988; USEPA 1987; WHO 1990; ATSDR 1993; HSE 1992).

\subsection{Extent of Exposure}

The principal concern of beryllium exposure to humans is in occupational settings. The potential for such exposure by inhalation exist in the basic production industry, beryllium alloy casting operations, ceramic beryllium-oxide 
parts manufacturing, and beryllium metal and alloy fabrication (Preuss 1991). It is estimated that workers potentially exposed to beryllium range from 30,000 (NIOSH 1972) to 800,000 (NIOSH 1978), although the latter estimate has been challenged as an overestimate (Preuss 1991).

To provide for review and ongoing evaluation of the acute and chronic forms of beryllium-induced disease, a Beryllium Case Registry was established in 1952. However, this Registry has not been maintained actively or uniformly in recent decades.

\subsection{Effects on Humans}

\subsubsection{Acute Beryllium Disease}

Acute beryllium-induced pulmonary disease, which is characterized by acute nasopharyngitis, tracheobronchitis, and chemical pneumonitis, results from exposure to relatively high levels of airborne beryllium (Ridenour and Preuss 1991; Kreibel 1988). For the last 40 years, acute beryllium disease has been associated solely with the extraction of beryllium from ore. However, the potential for contracting the disease only exists in operations that involve handling or extraction of soluble forms of beryllium (e.g., beryllium fluoride and beryllium chloride). It has been noted that virtually all workers exposed to concentrations above $1,000 \mu \mathrm{g} / \mathrm{m}^{3}$ contracted acute beryllium disease, but there has been no reported cases among workers who were exposed to less than $100 \mu \mathrm{g} / \mathrm{m}^{3}$. When removed from exposure, employees who contracted acute beryllium disease gradually improved over a period of several weeks to a few months. The last confirmed case of acute beryllium disease in the United States was in 1967.

\subsubsection{Chronic Beryllium Disease}

Chronic beryllium disease (CBD) was first described by Hardy and Tabershaw (1946) as a chronic, delayed-type chemical pneumonitis. It is characterized clinically by pulmonary symptoms that include dyspnea, nonproductive cough, and detriments in lung function, although symptoms can also include progressive weakness and fatigue, pain, and anorexia. Histologically, features of $\mathrm{CBD}$ include the presence of progressive, noncaseating granulomas, mononuclear cell infiltrates, and calcific inclusions (Freiman and Hardy, 1970). Recently, several authors reviewed the clinical features, pathology, diagnosis, and treatment of CBD (Rossman 1996; Meyer 1994; Rossman Pruess, and Powers 1991; Kriebel 1988). The disease results from the inhalation of airborne beryllium, and is most closely associated with the relatively insoluble forms (Eisenbud and Lisson 1983). The mean latency period for CBD may range from 1 to 40 years, with an incidence in exposed populations from 1 to $10 \%$. This latter feature led Sterner and Eisenbud (1951) to suggest an immunologically mediated basis for the disease and the possibility that genetic susceptibilities may exist. Dermal effects may also exist 
in response to skin contact with soluble salts or beryllium slivers, and these effects may range from contact dermatitis to dermal granulomas.

\subsubsection{Lung Cancer}

There has been considerable debate on the extent to which beryllium and its compounds should be regarded as a human lung carcinogen. Several groups have undertaken epidemiological research on beryllium workers from two general populations: all identifiable beryllium workers, and workers listed in the Beryllium Case Registry. Throughout the 1970s, the former group of workers formed the basis of reports by Wagoner et al. (1980) and by Mancuso (1980), whereas the second group was examined by Infante et al. (1980). These studies have been extensively reviewed and critiqued (USEPA 1987; ATSDR 1993; IARC 1993). The general tone of these reviews is that serious methodological problems with the studies prevented definitive conclusions to be drawn. For this reason, but in consideration of the demonstrable carcinogenicity of beryllium in certain animal models (see Section 2.4), beryllium was classified in the early 1990s as a demonstrated animal carcinogen and a suspect human carcinogen.

More recently, these same two cohorts were reanalyzed. Steenland and Ward (1991) described a small, yet statistically significant increase in lung cancer for cases listed in the Beryllium Case Registry versus the United States population. Interestingly, the mortality rate for lung cancer was greater among individuals with acute beryllium disease (possibly because of greater beryllium exposure) compared with those having CBD. Ward et al. (1992) examined 9225 beryllium workers from 7 beryllium plants and also noted a small, yet significant increase in the mortality rate for lung cancer from some, but not all of the plants. Presumably on the basis of these studies, the IARC (1993) voted to classify beryllium as a demonstrated lung carcinogen in

humans. In spite of these findings, however, beryllium is still classified as a suspected human lung carcinogen in the United States.

\subsection{Historical Aspects}

\subsubsection{Acute Beryllium Disease}

Acute beryllium disease was first reported in the United States by Van Ordstrand (1943) and Kolanz (1997). This disease is a chemical pneumonia, which for the last 40 years, has been solely associated with the extraction of beryllium from ore. Prior to 1950, acute beryllium disease was associated with the manufacture and usage of low-fired beryllium oxide in the fluorescent lamp industry. However, high-fired oxide used in the same application did not result in the disease. Hall et al. (1950) found that the low-fired oxide powder was actually an agglomeration of smaller particles, while the high-fired oxide was made up of larger particles. Also, low-fired oxide was much more soluble than high-fired oxide. 
Today, the potential for contracting acute beryllium disease only exists in facilities that handle or extract soluble forms of beryllium (e.g., beryllium fluoride and beryllium chloride). The last confirmed case of acute beryllium disease in 1967 was caused by welding on ventilation duct work containing beryllium fluoride residue. Thus, it appears that acute beryllium disease does not occur in operations involving insoluble forms of beryllium (such as metallic beryllium powder or dust, high-fired beryllium oxide powder or dust, or fumes or dust from alloys containing beryllium).

\subsubsection{Chronic Beryllium Disease}

As previously noted, CBD was first identified in 1946. In subsequent years, several hundred cases were identified and entered into the Beryllium Case Registry. Eisenbud and Lisson (1983) found a significant reduction in CBD among workers first exposed after 1950. Associated with the decreased incidence of CBD, in spite of increased beryllium use in the 1950s and 1960s, Eisenbud found a decrease in the latency period (Eisenbud, 1990). For various plants and beryllium-working operations, the estimated level of exposure did not correlate well with the incidence of CBD. The role of beryllium-specific sensitization was confirmed in both laboratory and clinical studies.

The identification of a CBD case in a DOE facility in 1984 resulted in increased scrutiny of both industrial hygiene practices and individuals working with beryllium. The lymphocyte proliferation test (LPT), combined with more definitive medical examinations, is now being used in large-scale programs to screen patients' blood or lung lymphocytes. The test involves placing the lymphocytes in cell culture with a soluble form of beryllium and measuring proliferation of the cells (see Section 2.5.2). To date, over 100 new cases of beryllium sensitization and/or CBD have been identified.

\subsubsection{Neighborhood Cases}

A curious feature of the early literature was the occurrence of several cases of CBD in people residing in the vicinity of beryllium plants. Although it was not possible to always estimate airborne beryllium concentrations near these plants, it was clear that air concentrations could not have been as large as within the plants. However, investigations concluded that insufficient personnel hygiene practices of plant workers, largely from laundering contaminated work clothes in the home, was responsible (Eisenbud 1982, 1990). These investigations also lead to the adoption in 1950 of the $0.01 \mu \mathrm{g} / \mathrm{m}^{3}$ concentration standard for air in the vicinity of beryllium plants.

\subsection{Animal Models}

\subsubsection{Biokinetics}

Most of our knowledge on the excretion biokinetics of beryllium in humans comes from experimental studies in laboratory animals. Limited information 
that exists on the topic has been recently summarized in various works (USEPA 1987; Reeves 1991a; ATSDR 1993; IARC 1993; Finch et al. 1996).

Systemic absorption of beryllium through the skin after dermal exposure or through the gastrointestinal tract after oral ingestion is low. Retention in the lung, distribution to other tissues and organs, and excretion are largely due to the physicochemical form of the beryllium inhaled. More soluble beryllium is cleared relatively quickly from the lungs, but can be retained longer, presumably due to precipitation into relatively insoluble forms. Forms of lower solubility, such as the metal or oxide, can be cleared following conventional lung kinetics of clearance of relatively insoluble particles, although toxicity induces delayed clearance (Finch et al. 1996), or by dissolution. Systemically distributed beryllium is retained predominantly in bone, but has been noted in other compartments. Excretion in feces is largely due to unabsorbed beryllium passing from the respiratory to gastrointestinal tract; urinary excretion is more important for systemically distributed beryllium (Reeves 1991b).

\subsubsection{Toxic and Immunological Effects}

Non-cancer toxic and immunological effects of beryllium compounds have been observed in systems ranging from cultured cells to intact animals (EPA 1987; WHO 1990; Reeves 1991b; ATSDR 1993; IARC 1993; Finch et al. 1996). At sufficiently high exposure levels, beryllium compounds can cause death in periods ranging from minutes to weeks. Beryllium is cytotoxic and can also induce severe, chronic inflammatory pulmonary responses even from single inhalation exposures to the metal.

Animal models have been useful in demonstrating the immunological nature of responses to beryllium. Barna et al. (1984) have demonstrated differential sensitivity of two strains of guinea pigs, suggesting a genetic component of response. Most of the components of human CBD have been demonstrated in either mice (Huang et al. 1992; Finch et al., 1996), rats (Votto et al. 1987), dogs, or monkeys (Finch et al. 1996). Unfortunately, an animal model that incorporates all the significant features of human CBD (including the progressive nature of the disease) has not yet been identified despite efforts by numerous investigators. The development of such a model would allow for investigation of many of the current uncertainties regarding responses to beryllium (see Section 2.5).

\subsubsection{Cancer}

Recent reviews of the carcinogenicity of beryllium compounds in various tissues of several species of laboratory animals can be found in various works (EPA 1987; WHO 1990; Reeves 1991b; ATSDR 1993; IARC 1993). Most notable have been bone cancer induced by various routes of exposure and, more pertinent to humans, lung cancer induced by inhalation or intratracheal instillation of several different beryllium-containing materials. Marked species differences in pulmonary carcinogenic responses to inhaled beryllium 
metal between rats (relatively susceptible) and mice (relatively resistant) have been observed (Finch et al. 1996). Experimental data are sufficient to permit both the EPA $(600 / 8-84 / 026 \mathrm{~F}, 1987)$ and IARC (1993) to conclude that beryllium and its compounds are demonstrated carcinogens in animals.

\subsection{Current Issues}

\subsubsection{Relationship Between Sensitization and Disease}

Because of the development and widespread use of the blood LPT within only the last decade, the relationship between Be-sensitization and the development of clinical CBD is not clear. While it is generally accepted that CBD cases were preceded by detectable sensitization, the extent to which sensitization, as measured by the LPT, predestines an individual to contract the clinical disease is not known. Some investigators have provided a few instances where this progression has occurred (Kreiss 1993a), but a definitive answer to the question must await followup of individuals who have recently been identified as sensitized, but who are clinically free of any signs of CBD.

\subsubsection{Current Large-scale Screening Programs}

Efforts are currently under way at two DOE sites (Rocky Flats and the Y-12 plant at Oak Ridge) and in the private sector to test current and former beryllium workers for Be-specific sensitization using the blood LPT. The largest effort is at Rocky Flats, where 4,268 workers have been tested (Stange et al. 1996). About 1,000 workers at Oak Ridge have been or will be tested.

Large-scale screening programs include an initial blood LPT test, follow-up tests if the initial test is positive, medical counseling, and possible removal from beryllium work. Follow-up tests may include a lung LPT and collection of a transbronchial biopsy sample for analysis of possible lung granulomas. Medical removal from Be-related work is problematic in the private sector where beryllium work may be the only business. It is anticipated that prospective followup of sensitized, asymptomatic individuals will provide important information on the relationship between beryllium-specific sensitization and the development of clinical CBD.

An enzyme-linked immunosorbent assay (ELISA) (a beryllium antibody test) was developed to screen individual employees for possible exposure to beryllium in the workplace (Clarke 1991). This exceptionally sensitive assay has been used to assess beryllium exposures in a variety of jobs (i.e., engineers, maintenance staff, filter replacement technicians, and laboratory workers), and has identified beryllium exposures within weeks at concentrations as low as $0.08 \mu \mathrm{g} / \mathrm{m}^{3}$ (Clarke 1993). It has also been shown to be effective at detecting antibodies in laboratory mice following inhalation exposures. 


\subsubsection{Effect of Physicochemical Form and Frequency of Exposure}

Despite a 50-year relationship between beryllium exposure and CBD, industrial hygiene assessments have not definitively identified the relationship among specific forms of beryllium, the frequency of exposure (single acute, chronic, or multiple episodic exposure), and the disease. It has been apparent for some time, however, that exposure to the less soluble forms of beryllium (e.g., beryllium metal or beryllium oxide), compared to more soluble forms, are more likely to be associated with CBD cases. Eisenbud and Lisson (1983) showed that machinists working with beryllium metal had the greatest risk of contracting CBD although recent data indicate that exposure to beryllium oxide, even when fired at relatively high temperatures, may be the more hazardous exposure (Kreiss 1996). Cases attributable to exposures to beryllium-containing alloys also exist, although these are apparently more rare (Levin 1991).

There is considerable uncertainty regarding the role of beryllium exposure frequency. CBD cases attributable to a single or only a few exposures are rare, but do exist (see Newman and Kreiss 1992 for details). As for the relative importance of low-level, chronic exposure, versus periodic "spikes" of exposure, neither industrial hygiene data on human exposures nor data from experimentation on animals permit this question to be adequately answered.

\subsubsection{Human Carcinogenicity}

Beryllium and its compounds was classified as a demonstrated human carcinogen by the IARC (1993) based on cohort epidemiology studies conducted by Ward et al. (1992) and Steenland and Ward (1991). The interpretation of the findings of these studies is controversial, and factors other than beryllium exposure might explain the results (MacMahon 1994; Vainio and Rice 1997; BISEC 1997). Some agencies in the United States classify beryllium as a suspect human carcinogen (USEPA 1987; ATSDR 1993). Thus, an unresolved dichotomy exists between Europe and the United States regarding the regulatory classification of beryllium as a human carcinogen.

\section{Standards and Regulations}

The Occupational Safety and Health Administration (OSHA), the National Institute for Occupational Safety and Health (NIOSH), and the American Conference of Governmental Industrial Hygienists (ACGIH) have established regulations, standards, and recommendations for beryllium and its compounds. The EPA has also defined regulatory limits for air, water, ground, and waste. 


\subsection{Occupational Limits}

In conformity with the limits established by OSHA and adopted by DOE , the 8-Hour Time Weighted Average (TWA) of $2 \mu \mathrm{g} / \mathrm{m}^{3}$ is the standard for DOE facilities.

To ensure consistent control of beryllium exposure to workers, it is useful to establish administrative limits below the occupational exposure limit, based on the distribution and upper variation of the actual data and an assessment of procedural and operational risks (Kolanz 1997). Site-specific administrative action levels should be established based on the assessment of both measured and potential risk to the worker, with different administrative limits set for different processes where appropriate. Administrative limits that are exceeded might

1. Trigger initial and additional monitoring.

2. Trigger exposure investigation.

3. Require engineering improvements or procedural modifications.

4. Require use of respiratory protection.

5. Shut-down operations while a problem is being addressed.

6. Require use of personal protective clothing.

7. Require special procedures (i.e., potential for airborne material release, decontamination, etc.).

8. Require special facilities (i.e., locker rooms, cleaning facilities, etc.).

9. Require implementation of programs and establishment of levels of controls.

10. Require implementation of medical monitoring and screening.

Items $1-5$ are typically operational decisions, while items $6-10$ are usually administrative in nature. For operational decisions, facilities should establish systems that utilize action levels which indicate when processes are beginning to fail and when to effect investigations to determine the cause of problems. Action levels selected to trigger administrative controls should establish decision points that are defined through risk assessment. For example, a decision to require showering at the end of the work day should be determined by an assessment of the potential for a worker to carry contamination home to their family. If clothing practices and locker room procedures are such that personal contamination to the hair, body, and personal clothing and belongings are not likely to occur, then showering may be optional or unnecessary.

Administrative action levels for operations can vary from facility to facility or area to area. This concept is akin to establishing process control charts to understand the variation in the data that affect the quality of production. A difference is that industry usually is seeking a value that falls between an 
upper and lower control limit, while those involved in exposure monitoring are only interested in the upper control limit. In using such a system, it is good practice to require operations personnel to record and chart the exposure data in their work area. Such practice encourages a positive attitude toward the Beryllium Control Program and participation in the control and remedy of exposure concerns.

Brush Wellman (Kolanz 1997) uses an action level of $>0.1 \mu \mathrm{g} / \mathrm{m}^{3}$ to implement medical monitoring and screening. All other action levels are based on the assessment of both measured and potential risk to the worker. For example, the typical exposure for a worker performing a drum change between a dust collector cyclone and the collection drum below is typically below $0.2 \mathrm{~g} / \mathrm{m}^{3}$, which is deemed too low to require the use of respiratory protection. However, the potential exists for material to bridge across the lower section of the cyclone and potentially release during such an activity. Therefore, all workers must wear respiratory protection while performing drum changes based on the assessment of risk.

\subsubsection{OSHA}

The OSHA General Industry Standard, 29 CFR 1910.1000, establishes the following permissible exposure limits for beryllium:

- 8-Hour Time Weighted Average-2 $\mu \mathrm{g} / \mathrm{m}^{3}$. An employee's exposure to beryllium and its compounds in any 8 -hour work shift of a 40-hour work week shall not exceed $2 \mu \mathrm{g} / \mathrm{m}^{3}$.

- Acceptable Ceiling Concentration- $5 \mu \mathrm{g} / \mathrm{m}^{3}$. An employee's exposure to beryllium and its compounds shall not exceed $5 \mu \mathrm{g} / \mathrm{m}^{3}$ at any time during an 8-hour shift.

- Acceptable Maximum Peak Concentration-25 $\mu \mathrm{g} / \mathrm{m}^{3} \mathrm{An}$ employee's exposure to beryllium and its compounds shall not exceed $25 \mu \mathrm{g} / \mathrm{m}^{3}$, the acceptable maximum peak above the acceptable ceiling concentration, for a maximum duration of 30 minutes. (This limit was set to eliminate acute beryllium disease from exposure to soluble forms of beryllium.)

These exposure limits were adopted from ANSI Z37.29-1970 and can also be found in 29 CFR 1926 (Construction).

The OSHA beryllium requirements for welding and cutting on berylliumcontaining base or filler metals are as follows:

Welding or cutting indoors, outdoors, or in confined spaces involving beryllium-containing base or filler metals shall be done using local exhaust ventilation and airline respirators unless atmospheric tests under the most adverse conditions have established that the workers' exposure is within the acceptable concentrations defined by 29 CFR 1910.1000. In all cases, workers in the immediate vicinity of the welding or cutting operations shall be protected as necessary by local exhaust ventilation or airline respirators. 
This requirement can be found in 29 CFR 1910.252(c)(8) (General Industry) and in 29 CFR 1926 (Construction). It also can be found in the OSHA Technical Manual - CPL 2-2.20B ((USDOL 1996) references beryllium in Chapter 1, "Personal Sampling for Air Contaminants," Appendix 1-E, "Sampling for Special Analyses," under "Samples Analyzed by Inductively Coupled Plasma (ICP)" and in Chapter 2, "Sampling for Surface Contamination."

\subsubsection{NIOSH}

NIOSH has recommended that workers should not be exposed to a concentration of beryllium exceeding $0.5 \mu \mathrm{g} / \mathrm{m}^{3}$ at any time (NIOSH 1977). $\mathrm{NIOSH}$ has identified beryllium as an occupational carcinogen based on the following definition: "Potential occupational carcinogen means any substance, or combination or mixture of substances that causes an increased incidence of benign and/or malignant neoplasms or a substantial decrease in the latency period between exposure and onset of neoplasms in humans or in one or more experimental mammalian species as the result of any oral, respiratory, or dermal exposure, or any other exposure which results in the induction of tumors at a site other than the site of administration. This definition also includes any substance which is metabolized into one or more potential occupational carcinogens by mammals."

\subsubsection{ACGIH}

The ACGIH has established an 8-hour time-weighted average (TWA) threshold limit value (TLV) of $2 \mu \mathrm{g} / \mathrm{m}^{3}$ for beryllium and its compounds (ACGIH 1996a, 1996b). The ACGIH lists beryllium and its compounds as an A2 suspected human carcinogen. The ACGIH explains this classification by indicating that the agent is carcinogenic in experimental animals at dose levels, by route(s) of administration, at site(s) of histologic type(s), or by mechanism(s) that are considered relevant to worker exposure. Available epidemiologic studies are conflicting or insufficient to confirm an increased risk of cancer in exposed humans.

\subsection{Environmental Limits}

The Environmental Protection Agency (EPA) has promulgated a number of regulations involving beryllium and its compounds that are summarized below. Additional details can be found in Appendix A of this report.

\subsubsection{Air Programs}

The EPA's National Emission Standard for Beryllium can be found in 40 CFR 61. This standard states that "emissions to the atmosphere from stationary sources shall not exceed $10 \mathrm{~g}$ of beryllium over a 24-hour period, except that an owner or operator may request approval to meet an ambient 
concentration limit on beryllium in the vicinity of the stationary source of $0.01 \mu \mathrm{g} / \mathrm{m}^{3}$ averaged over a 30-day period."

\subsubsection{Water Programs}

The Federal Water Pollution Control Act, 40 CFR 116.4, designates several beryllium compounds as hazardous substances. Spills of these materials are subject to reportable quantities (RQ) requirements, as specified in Table 3-1.

The EPA has set the drinking water standard for beryllium at 0.004 part per million (ppm) to protect against the risk of adverse health effects. In 40 CFR 141.62 (National Revised Primary Drinking Water Regulations: Maximum Contaminant Level), the level is set at $0.004 \mathrm{mg} / \mathrm{l}-$ which is equivalent to 0.004 ppm.

Table 3-1. Reportable quantities of designated hazardous substances, as specified in 40 CFR 116.4, Section 311.

\begin{tabular}{|l|l|c|}
\hline \multicolumn{1}{|c|}{ Material } & \multicolumn{1}{|c|}{ CAS number } & RQ, in $\mathrm{lb}(\mathrm{kg})$ \\
\hline Beryllium chloride & $7787-47-5$ & $1(0.454)$ \\
\hline Beryllium fluoride & $7787-49-7$ & $1(0.454)$ \\
\hline Beryllium nitrate & $7787-55-5$ or $13597-99-4$ & $1(0.454)$ \\
\hline
\end{tabular}

\subsubsection{Superfund Amendments and Reauthorization Act (SARA) Regulations}

Table 3-2 gives the hazard substances and reportable quantities and is reproduced from Table 302.4 in 40 CFR 302.4(b).

\begin{tabular}{|c|c|c|c|c|c|}
\hline $\begin{array}{l}\text { Hazardous } \\
\text { Substance }\end{array}$ & CAS number & Statutory RQ & $\begin{array}{c}\text { RCRA } \\
\text { waste \# }\end{array}$ & $\begin{array}{l}\text { Final } \\
\text { RQ } \\
\text { category }\end{array}$ & $\begin{array}{c}\mathrm{RQ} \text { in } \mathrm{lb} \\
(\mathrm{kg})\end{array}$ \\
\hline Beryllium & $7440-41-7$ & $1^{*}$ & P015 & A & $10(4.54)$ \\
\hline $\begin{array}{l}\text { Beryllium and } \\
\text { its compounds }\end{array}$ & $\mathrm{N} / \mathrm{A}$ & $1^{*}$ & & & \\
\hline $\begin{array}{l}\text { Beryllium } \\
\text { chloride }\end{array}$ & $7787-47-5$ & 5000 & & $x$ & $1(0.454)$ \\
\hline Beryllium powder & $7440-41-7$ & $1^{*}$ & P015 & A & $10(4.54)$ \\
\hline $\begin{array}{l}\text { Beryllium } \\
\text { fluoride }\end{array}$ & $7787-49-7$ & 5000 & & $x$ & $1(0.454)$ \\
\hline Beryllium nitrate & $13597-99-4$ & 5000 & & $x$ & $1(0.454)$ \\
\hline \multicolumn{6}{|c|}{$\begin{array}{l}\text { * Indicates that the } 1-1 b \text { RQ is a CERCLA statutory RQ and is subject to change when } \\
\text { the assessment of potential carcinogenicity is completed. The agency may adjust the } \\
\text { statutory RQ for these hazardous substance in a future rulemaking, but until then the } \\
\text { statutory RQ applies. }\end{array}$} \\
\hline
\end{tabular}




\section{Exposure Assessment}

\subsection{General}

Exposure monitoring (Hawkins, 1991) is a key element of a good industrial hygiene beryllium control program. It allows for identification of beryllium sources in the workplace, evaluates the workplace for compliance with standards, and is essential in maintaining exposures well below the permissible limit. Monitoring also evaluates the effectiveness of controls and housekeeping efforts.

All facilities conducting operations with a potential for exposure to beryllium or its compounds must have an Exposure Assessment Plan that

- Identifies all potential exposures to beryllium.

- Ranks exposure hazard potential.

- Identifies employees who may be potentially exposed to beryllium.

- Contains monitoring guidelines for characterizing exposures.

- Documents, communicates, and records monitoring results.

- Contains guidelines for determining monitoring frequency.

- Contains an action plan for exposures exceeding established action levels and/or PELs.

- Contains procedures for protecting employees doing non-routine or uncontrolled operations.

- Contains mechanism to initiate additional monitoring following changes in processes, production, materials, controls, work practices, or personnel.

The Exposure Assessment Plan should be specific to a facility's operations, based on sound professional industrial hygiene judgment, and should identify and characterize all potential beryllium exposures. It also should be updated annually or when significant operations, processes, or procedures are changed.

\subsection{Air Monitoring}

A range of sampling technologies and methods for exposure assessment are needed to measure the level of beryllium exposure control (Kolanz 1997). Restricting exposure assessment to a single technology or method would not be beneficial in minimizing exposure to airborne beryllium. An exposure assessment strategy must not be limited to worker sampling, with a standard setup consisting of a battery-powered portable pump pulling air through a 37-mm, 0.8-micron mixed cellulose ester filter at about 2 liters per minute (lpm). This sampling method is adequate for defining a time-weighted 
average exposure to a worker during a typical 8-hour work shift, but does little to assist industrial hygienists in identifying the cause of variation in exposure during the work day. Assessment of variation is critical to determining the best control strategies to apply. The use of smoke tests to determine general air patterns in the work area can be very informative.

Standard personal sampler configurations can be used to sample air for periods as short as 15 minutes. However, such samples can be compromised by the limit of analytical detection because the sample quantity may be insufficient due to the low sampling rate. High-volume sampling (about 250$350 \mathrm{lpm}$ through a Whatman 41 filter) can be used to sample for periods as short as one minute. These samples allow for greater analytical detection and efficient use of investigative time to analyze activities or systems suspected of causing short-term, high-level exposures. Use of high-volume samplers to quantifiably confirm or locate systems that are beginning to fail is not yet readily possible by any other means. These samplers can be used to identify intra-day activities requiring respiratory protection. A limitation of these samplers is the time it takes to get the results of analysis; this is also true for the standard personal samplers.

A real-time beryllium analyzer may be commercially available later in 1997 . This analyzer will be used in much the same manner as high-volume samplers for exposure assessment, but will provide immediate air concentrations. It will also have an alarm to warn of system failure. The limitations of this analyzer are cost (about $\$ 140,000$ ) and portability (units must be moved via a small cart).

\subsubsection{Personal Monitoring}

Air monitoring of an employee's breathing zone is the best method of estimating beryllium exposure. All work activities must be characterized for both full-shift and potential-peak exposures. New, recently modified, or previously uncharacterized operations will require an intensive initial exposure evaluation. Personal monitoring and sample analysis should be conducted in accordance with procedures in the OSHA Technical Manual (USDOL 1996) and the NIOSH method 7102 (NIOSH 1987), or equivalent.

Until monitoring data repeatedly demonstrate that exposure levels are below an action level, each work shift will require monitoring as suggested in Table 4-1. While it is desirable to monitor all employees performing a specific operation, it is not always feasible to do so for a large workforce. In such cases, representative monitoring may be appropriate. Representative groups should consist of at least $25 \%$ of the employees performing the actual work (not based only on job title or classification) and include those individuals with the highest expected exposure. 


\begin{tabular}{|c|c|}
\hline IF the potential level is & THEN \\
\hline$<0.2 \mu \mathrm{g} / \mathrm{m}^{3}$ & Monitoring is not necessary. \\
\hline $0.2 \mu \mathrm{g} / \mathrm{m}^{3}$ to $1 \mu \mathrm{g} / \mathrm{m}^{3}$ & $\begin{array}{l}\text { Monitoring is required } \\
\text { initially, then it must be } \\
\text { repeated at least annually. }\end{array}$ \\
\hline$>1 \mu \mathrm{g} / \mathrm{m}^{3}$ to $<2 \mu \mathrm{g} / \mathrm{m}^{3}$ & $\begin{array}{l}\text { Routine monitoring is } \\
\text { required. }\end{array}$ \\
\hline $\begin{array}{c}>2 \mu \mathrm{g} / \mathrm{m}^{3} \text { (at the PEL or above and when } \\
\text { respirator is worn) }\end{array}$ & Daily monitoring is required. \\
\hline
\end{tabular}

Sometimes an increase in sampling frequency is necessary to improve communication and change culture. For operations where it is reasonable to expect that brief, high concentrations of beryllium may be possible, the initial monitoring should include short-term, 15-minute breathing zone samples. This is required in addition to full-shift monitoring, and should be done during operations where high-level exposures are possible.

The ACGIH has proposed a 15-minute Short-Term Exposure Limit (STEL) of $10 \mu \mathrm{g} / \mathrm{m}^{3}$ for beryllium. This is equivalent to an $8-\mathrm{hr}$ TWA of $0.31 \mu \mathrm{g} / \mathrm{m}^{3}$. An administrative STEL of $5 \mathrm{~g} / \mathrm{m}^{3}$ might be considered as a part of the facility's Exposure Assessment Plan. A sampling system run at $4 \mathrm{lpm}$ for 15 minutes would collect $0.3 \mu \mathrm{g}$ of beryllium on the filter if the air concentration was $5 \mu \mathrm{g} / \mathrm{m}^{3}$. This would be reasonable to measure with acceptable accuracy and precision.

When repeated full-shift and/or short-term monitoring results demonstrate that exposures are below an action level and processes and controls are stabilized, monitoring frequency may be reduced. The monitoring frequency should be determined using sound professional industrial hygiene judgment and should be based on the processes, controls, and workforce. It should also be incorporated into the facility Exposure Assessment Plan. As a minimum, quarterly monitoring is recommended when the potential for exposure is low; monitoring results are consistently below an action level; and processes, controls, and work practices are well characterized and stable.

In the United Kingdom, the Atomic Weapons Establishment (AWE) has successfully monitored all beryllium workers on every shift. Frequent monitoring

- Provides greater assurance that employees are not overexposed.

- Allows for characterization of the variability of exposures in the workplace.

- Identifies individual work practices that contribute to high exposures. 
- Acts as a continuing check on the efficacy of workplace controls.

- Identifies problems before they result in employee overexposure.

Furthermore, the cost of frequent monitoring is relatively small compared to that of an employee overexposure or the shutdown of an operation due to control failure.

Non-routine, uncharacterized, or uncontrolled operations such as maintenance, repair, cleaning, reconfiguration, or special projects have some of the highest potential for exposure to beryllium. Therefore, always assume that the PEL may be exceeded when performing such operations and use the appropriate personal protective equipment (PPE) and controls. Where respirators are required and there is reasonable potential for the PEL to be exceeded, make sure that daily monitoring is conducted.

Decontamination and decommissioning (D\&D) operations at former beryllium facilities may result in unexpected exposures to beryllium. In such cases, representative monitoring should be conducted for each task or work group as a minimum.

Periodic monitoring is not necessary where there is no reasonable potential for beryllium exposure. However, the facility Exposure Assessment Plan should include a statement of how this decision was reached.

It is reasonable that the occurrence of beryllium disease is a function of the size of inhaled particles. Consideration should therefore be given to conducting particlesize monitoring. This can be as simple as using a cyclone to decrease the collection efficiency of larger particles or could involve the use of any number of particle-size distribution samplers (e.g., cascade impactors).

\subsubsection{Area Monitoring}

Area monitors are useful for characterizing sources of beryllium exposure, checking the effectiveness of control systems, and measuring the air quality in general work areas and adjacent areas. However, they are not reliable for estimating worker exposure.

When used to supplement personal monitoring, area monitors should be placed between the worker and the beryllium source or along the expected path of the exposure. This allows for monitoring of an area that is equal to or greater than the worker's potential exposure.

Area monitoring may require high flow rates and/or long sampling times to achieve adequate sensitivity. The frequency and location of air quality measurements should be identified in the facility beryllium Exposure Assessment Plan. 


\subsubsection{Surface Monitoring}

Surface swipe sampling is used to monitor the effectiveness of housekeeping efforts and to identify the presence of potential beryllium hazards. The OSHA Technical Manual (USDOL 1996) suggests the use of this method in the workplace to measure the presence of accumulated material (e.g., beryllium) that "may become suspended in air and may contribute to airborne exposures."

Facilities should conduct swipe sampling in accordance with procedures in this manual (or equivalent) to ensure that all work surfaces are free of excessive accumulation of beryllium dust. (The procedures used should be documented in the Facility Exposure Assessment Plan.)

Surface contamination limits may be established to prevent worker exposure and to minimize surface contamination levels. Where such limits are exceeded, corrective actions such as a review of the process; cleaning of contaminated surfaces; and appropriate changes to controls, procedures, and/or housekeeping practices would be initiated. Table 4-2 lists suggested maximum surface contamination levels and recommended corrective actions.

\begin{tabular}{|c|c|}
\hline IF the level is & THEN \\
\hline $\begin{array}{l}<1 \mu \mathrm{g} / 100 \mathrm{~cm}^{2} \text { (dry swipes) } \\
<5 \mu \mathrm{g} / 100 \mathrm{~cm}^{2} \text { (wet swipes) }\end{array}$ & $\begin{array}{l}\text { Clean the surface. The surface may be } \\
\text { released to the public. }\end{array}$ \\
\hline $\begin{array}{l}1-10 \mu \mathrm{g} / 100 \mathrm{~cm}^{2} \text { (dry swipes) } \\
5-50 \mu \mathrm{g} / 100 \mathrm{~cm}^{2} \text { (wet swipes) }\end{array}$ & $\begin{array}{l}\text { No action is required. This level is } \\
\text { acceptable in designated beryllium- } \\
\text { processing areas. }\end{array}$ \\
\hline $\begin{array}{l}10-200 \mu \mathrm{g} / 100 \mathrm{~cm}^{2} \text { (dry swipes) } \\
50-1000 \mu \mathrm{g} / 100 \mathrm{~cm}^{2} \text { (wet swipes) }\end{array}$ & $\begin{array}{l}\text { No action is required. This level is } \\
\text { acceptable in an access-controlled } \\
\text { beryllium area. }\end{array}$ \\
\hline $\begin{array}{l}>200 \mu \mathrm{g} / 100 \mathrm{~cm}^{2} \text { (dry swipes) } \\
>1000 \mu \mathrm{g} / 100 \mathrm{~cm}^{2} \text { (wet swipes) }\end{array}$ & $\begin{array}{l}\text { Stop work. Assess, investigate, and/or } \\
\text { decontaminate the area as necessary. }\end{array}$ \\
\hline $\begin{array}{l}\text { NOTE: In the literature, units of } \mu \mathrm{g} / \mathrm{ft}^{2} \\
9.3 \mu \mathrm{g} / \mathrm{ft}^{2}, \text { but the conversion } 1 \mu \mathrm{g} / 100\end{array}$ & $\begin{array}{l}\text { netimes found. } 1 \mu \mathrm{g} / 100 \mathrm{~cm}^{2}= \\
0 \mu \mathrm{g} / \mathrm{ft}^{2} \text { is commonly used. }\end{array}$ \\
\hline
\end{tabular}

It should be noted that swipe sampling will not detect beryllium that is difficult to remove, sealed beneath paint, or imbedded in building materials. Beryllium that is not detectable by swipes could potentially become airborne during D\&D or remodeling operations. Surface swipes should not be the sole method of identifying potential beryllium hazards for operations that will 
involve demolition, resurfacing, remodeling, or other procedures that will significantly disturb structures or building materials.

Surface swipes should not be used to measure worker exposure or demonstrate regulatory compliance. A number of authors (Mitchell 1966; Lichtenwalner 1992; Klingner 1994) have found that surface swipe sampling lacks the precision required for regulatory purposes. It is not highly reproducible, not completely efficient in removing material, and shows variable recovery from different surfaces. After an extensive review of the literature and survey of industrial hygienists, Caplan (1993) concluded that, "there is no general quantitative relationship between surface contamination and air concentration that is adequate for estimating inhalation dose with sufficient accuracy for use in Industrial Hygiene." Areas where air velocity keeps particles entrained could conceivably have hazardous air concentrations of beryllium, yet still have relatively low surface contamination levels. Likewise, areas with low air movement, areas that are not likely to be disturbed, or areas that are not accessible by workers could have considerable surface contamination without presenting a significant airborne beryllium hazard. Despite these drawbacks, surface swipe techniques are still a useful tool for industrial hygienists.

\section{Controls for Beryllium Exposure}

Worker exposure to airborne beryllium and its compounds may cause CBD, an immunological disease. Thus, the approach for controlling beryllium exposure is different than that for many other health hazards. Standard industrial hygiene practice for controlling chemicals is to maintain exposures below the PEL and/or TLV, whichever is lower. However, this practice may not be adequate to protect workers from contracting CBD. Although beryllium has one of the lowest exposure limits, exposure at the PEL or TLV takes approximately 2000 10-m diameter particles on an 8-hour sample filter.

As with any health hazard, engineering controls, administrative controls, good work practices, and personal protective equipment (in order of importance) should be implemented to minimize exposure in workplaces where beryllium is in use. Exposure levels can vary greatly, depending on work practices in use and on supervision. Consequently, training is an important aspect of a Beryllium Exposure Control Program. It is also important to understand that, in dealing with beryllium, one must, more carefully than is customary, assess the workplace, operations, tasks, and potential exposure of each worker.

The objectives of a Beryllium Exposure Control Program are to minimize

- Airborne concentrations.

- The potential for and spread of contamination. 
- The number of times of exposure per individual.

- The number of employees who may be potentially exposed. 


\subsection{Engineering Controls}

Engineering controls normally include ventilation and such devices as local ventilation exhaust hoods, glove boxes, and enclosures. Employers should make every reasonable effort that is technically feasible to apply such controls to operations to assure that exposures to beryllium are minimized. Whenever possible, cutting, grinding, machining, sanding, or processing of solid beryllium should be done wet to control beryllium particulates at the source.

\subsubsection{Ventilation}

There are two basic types of ventilation: general and local. With general ventilation, incoming fresh air dilutes any contaminants to below the occupational exposure limit. General ventilation is normally used for lowtoxicity contaminants emitted at relatively low rates, but is not acceptable for toxic materials such as beryllium. Local ventilation removes toxic materials from the air by drawing them away from the worker into an exhaust system. An exhaust hood or suction device at the point of contact of a machining operation are examples of local ventilation. Local ventilation should be used for beryllium operations.

Close Capture Systems. These include local, ventilated contaminant enclosures. The design and air flow of such enclosures should be reviewed to ensure that they meet the design criteria in Industrial Ventilation, A Manual for Recommended Practice (ACGIH, 1995). Typical air-flow requirements are 100-125 linear $\mathrm{ft} / \mathrm{min}$ for exhaust-hood enclosures and $300 \mathrm{cfm} / \mathrm{ft}^{2}$ of opening for machine enclosures.

Hood configurations and airflow rates are critical design features for face velocity. Total (or near total) containment with ventilation is the most effective method in controlling significant sources of dust or fume.

Insufficient face velocity through ventilation openings allows toxic materials to become or remain airborne outside hoods or enclosures and potentially to be drawn into employees' breathing zones. Therefore, hood and enclosure designs must be specific to the actual operation. For example, the face velocity for a hood designed to capture chips emitted at high velocity from a grinding operation will need to be higher than that for a hood designed to contain an operation involving fine dust.

Where air is removed from an area, make-up air must be supplied. Make-up air systems should be constructed to avoid drawing in contaminated exhaust air or becoming contaminated with other toxic or irritating materials (e.g., diesel exhaust from trucks at a loading dock or exhaust from other laboratory hoods). For work areas that routinely process beryllium (i.e., at least monthly), visual indicators such as audible alarms, tell-tale power lights, or flow indicators should be installed at each workstation to show that the ventilation is operating properly. Daily operational checks of engineering controls also should be conducted before beginning work to ensure that the 
systems are operating and air is circulating through them. A thorough check of exhaust ventilation systems should be conducted periodically (perhaps quarterly) under operating conditions to ensure continued operation at design specifications and to minimize exposure to airborne beryllium. Poorly maintained ventilating systems lose effectiveness over time.

Engineering controls should also be checked after any change in work operations or equipment (that might affect the controls) to ensure that such changes do not impair or overwhelm the system's efficacy and that all design specifications are met. Beryllium operations should not be resumed until the system is operating properly.

Exhaust Air Cleaning Systems. Exhaust from routine beryllium-processing operations that could produce airborne particulates should be vented to the environment through an approved high-efficiency particulate air (HEPA) filter.

\subsubsection{Other Controls}

Wet Methods. In most cases, airborne beryllium levels can be controlled to acceptable levels if coolant flooding is used during machining operations (i.e., surface milling, turning, drilling). The use of coolants will also control airborne materials during hand sanding, light deburring, or handling of oxidized material. Hand filing or hand sanding may be performed submerged in deionized water.

Isolation. For operations with a high probability for generating airborne beryllium, consider isolating employees in a control room.

\subsection{Administrative Controls}

Administrative controls can be inexpensive methods and effective supplementary means for minimizing employee exposure to beryllium after engineering controls have been applied. For example, the study of beryllium processes and operations to determine ways to lower exposures can produce sizable reductions in exposure. Administrative controls include

- Maintaining work conditions or operations to reduce exposure rather than using devices to remove contaminants.

- Establishing limited access zones.

- Scheduling maintenance operations that generate airborne beryllium during times when most employees are not in the immediate area.

- Arranging operations, schedules, or equipment such that fewer persons will be exposed or workers will be exposed for shorter periods or to lower concentrations of beryllium. 
Employee rotation is prohibited; the practice of exposing one worker to the maximum allowable concentration of beryllium in the morning and exposing a second worker to the maximum allowable concentration in the afternoon merely increases the total number of employees that will be exposed to airborne beryllium and is antithetical to the objective of minimizing exposure.

- Developing site-specific safety procedures for beryllium-processing operations that are capable of generating respirable contamination. Examples of such processes are cutting, machining, welding, polishing, or decontaminating beryllium and its compounds or alloys. Safety procedures should include any hazards in the area and identify the necessary controls.

- Developing maintenance safety procedures and pre-cleaning requirements for all beryllium-contaminated equipment. No procedure is needed for work with beryllium-alloy parts that contain less than $2 \%$ beryllium (e.g., electrical contact strips or springs) as long as no grinding or filing is done.

\subsubsection{Restricted Access Areas}

A beryllium "restricted access area" is established in locations where there is the potential for exposure to airborne beryllium and where there is concern for the spread of beryllium contamination to uncontrolled areas. Restricted access areas are established to limit the number of individuals potentially exposed, to provide formality of operations for personnel who enter the location, and to limit spread of contamination. The boundaries of a restricted access area is determined by an industrial hygienist.

The controls for restricted access areas may vary from a simple barricade around the designated area, with a small contamination reduction zone for doffing of contaminated personal protective equipment, to a facility where access is gained only through a change room. Restricted access areas can also be temporary if the beryllium activity is temporary. The controls for these areas depend on the level of airborne or surface contamination. However basic controls are required such as demarcating the area from the rest of the workplace using appropriate physical barriers and signs and having storage capability outside the area for clean personal protective equipment and a contamination reduction zone with containers for booties, outer garments, and respirators. Additional controls may be necessary to limit access to operations requiring respiratory protection and to areas where there are high airborne concentrations. A restricted access area is not generally needed for beryllium metal storage locations.

A record should be kept of all individuals who enter restricted access areas. 


\subsubsection{Change Rooms and Shower Facilities}

Regulated areas should have a decontamination facility consisting of a change room for removal of contaminated clothing, a shower, hand-washing facilities, and a clean room for storing and donning street clothing. Change rooms should be located adjacent to regulated areas, particularly in highhazard facilities. Where this is not feasible due to changing operations (e.g., maintenance and research activities that are short-term, small scale, or low hazard), soiled overclothes and equipment may be removed in the regulated area. The clean room should be separate from the change room and maintained at negative pressure.

High-hazard fixed operations with the potential for beryllium exposure require engineering controls (e.g., glove boxes) to prevent exposure and therefore avoid the use of respirators. These operations should be performed so that they do not require a regulated area or exceed the PEL/TLV or ceiling limit.

High-hazard nonfixed operations usually involve maintenance activities (e.g., repair of heavily contaminated ducts or changing of heavily contaminated filters) that could generate visible amounts of dust. Therefore, asbestos removal procedures including the use of polyethylene enclosures with three-chamber decontamination units, clothes changing, shower, waste handling, decontamination, and dust suppressant techniques (e.g., wet procedures) should be employed.

Low-hazard operations would require a regulated area if there is a reasonable potential for the PEL or ceiling limit to be exceeded. Where the hazards are sufficiently low and established limits will not be exceeded, a regulated area would not be required.

Regulated areas may range from a maintenance location, separated only by barrier tape, to a research lab or a machine shop with well-designed engineering controls (e.g., hoods and local ventilation). Most well-controlled fabrication and laboratory-scale operations fall into this category, provided there are no unusual circumstances that present a high risk for contamination.

Protective clothing may be required to prevent exposure at or above established administrative action levels. It is also good practice to require the use of company-provided coveralls and undergarments (including additional outer coveralls if the potential exposure exceeds the PEL/TLV) as well as encourage good personal hygiene (showering) where potential action level exposures exist.

Active and conscientious use of change rooms, shower, and hand-washing facilities protects both the employee and his/her family from exposure.

\subsubsection{Personal Hygiene}

Beryllium is not ordinarily hazardous if ingested. However, employees must not smoke; drink; eat; or store tobacco products, beverages, and food in beryllium processing areas. 
Employees should exercise good personal hygiene. The potential to spread contamination is the deciding factor in establishing personal hygiene facilities. Shower facilities are required if it is possible for workers to spread contamination to their homes through contaminated hair, shoes, or undergarments. As a general rule, if an operation requires respirator use, showering should be required prior to going home or getting into street clothing.

\subsubsection{Warning Signs and Labels}

Limited access areas should be clearly designated with warning signs such as that below. Refer to the manufacturer's material safety data sheet (MSDS) for guidance on labeling materials and wastes.

\section{DANGER \\ BERYLLIUM DUST (or FUME) \\ Inhalation of Dust or Fumes May Cause \\ Serious Chronic Lung Disease \\ Potential Cancer Hazard \\ AUTHORIZED PERSONNEL ONLY}

\subsubsection{Recordkeeping}

Employers are required to maintain exposure monitoring and medical surveillance records for their employees. Exposure-monitoring records must be kept for the duration of employment or 30 years beyond employment, whichever is longer. Medical surveillance records must be retained for 75 years. Medical records, like exposure-monitoring records, can provide useful information on the causes and prevention of diseases.

Exposure monitoring records for employees should include

- The employee's name, job classification, and exposure results, as well as other employees whom the measurement is intended to represent.

- The dates, duration, and number of samples taken.

- A description of the procedures used to determine representative employee exposures and sampling.

- A description of the sampling and analytical procedures used and their accuracy.

- The type of protective equipment, if any, worn by the monitored employee.

- A notation of any conditions, if any, that might have affected the sampling results. 
Because medical tests over time may provide important information, employees' medical records should include

- Written reports prepared by the attending physician.

- Occupational medical history, including complaints that may be related to beryllium exposure.

- The results of all medical tests, including those recommended by the physician.

Where the potential for exposure may be higher, an effective occupational health data management system should be used to identify the employees or tasks involved. This system should allow for query of information by date, location, employee, and operation or task; and for electronic collection of information.

\subsubsection{Training and Education}

All personnel (i.e., beryllium workers who work directly with the material, their supervisors, and others less directly involved) who may be exposed to airborne beryllium or surfaces contaminated with removable beryllium must be informed of the potential health hazards associated with occupational exposure to beryllium.

The OSHA Hazard Communication Standard (29 CFR 1910.1200) requires employers to provide all employees information on the physical and health hazards of chemicals, safe handling precautions, and emergency and first-aid procedures to prevent or minimize hazards resulting from chemical substances. It also requires employers to establish a Hazard Communication Program that includes guidance for labeling containers, completing MSDSs, and developing training programs.

The following is an example of a training program designed to meet most facilities needs:

Tier 1. This is general beryllium awareness training. It covers the basic training requirements of 29 CFR 1910.1200, methods for controlling beryllium exposure, and the organization's beryllium control program. This training should be required for all employees who work with beryllium and their supervisors, regardless of whether there is a potential for airborne exposure; medical personnel; emergency responders; industrial hygiene personnel, industrial hygiene technicians; and maintenance, waste, and other facility personnel. It should be conducted prior to beginning working and periodically (not necessarily annually) thereafter.

Tier 2. This training is more in-depth than Tier 1, and is required for all employees who enter restricted access areas. It covers current methods of controls for minimizing exposure levels; the exposure control program, with current examples; lessons learned; the medical surveillance program; and the proper use and limitations of personal 
protective equipment. A written and practical exam could be used to ensure that employees meet the training objectives. Training should be done prior to entering a restricted access area and periodically thereafter.

Tier 3. This type of training is operation specific and, since minimizing exposures depends on personal work habits, is highly recommended. Training can be accomplished by reviewing the procedures and controls for the operation and by having an experienced operator provide on-the job training (OJT), with input from an industrial hygienist.

\subsection{Housekeeping}

Provisions should be established to ensure that housekeeping practices are performed regularly and thoroughly to reduce beryllium contamination. Custodial employees who work in beryllium areas may be potentially exposed above the occupational exposure. Employees who become exposed while performing custodial and maintenance procedures (e.g., replacing filters and cleaning internal surfaces of glove boxes) should be monitored to determine the level of exposure and need for protective equipment.

All beryllium parts (including contaminated parts) and equipment should be contained in plastic bags or tape should be applied over all exposed surfaces.

Beryllium work areas should be maintained at a negative pressure, with respect to adjacent areas, to prevent the migration of contamination. Contamination should be confined to the smallest area within the room feasible. The walls and floors in these areas should be made of smooth, nonporous material for easy decontamination.

All surfaces in beryllium facilities should be free of accumulations of beryllium dust. This will minimize the amount of dust entrained into the air from contaminated floors, work surfaces, equipment and furnishings, windows and windowsills, doors and door frames, rafters, and other supporting structures.

A HEPA vacuum or wet cleaning methods, or both, should be used to clean floors and other surfaces to minimize the generation of airborne beryllium dust. Acceptable wet cleaning methods include the use of low-pressure water streams; mobile wet scrubber units, wet floor mops, and wet wipes, sponges, and cloths.

Beryllium-contaminated dust and debris collected by portable or mobile vacuum systems should not be released into the workplace atmosphere. Dedicated central vacuum cleaners or HEPA-type portable vacuum cleaners should be used to cleanup beryllium. Vacuuming systems that discharge inside a building should be equipped with HEPA filters because they have a high degree of capture efficiency for particulates. Dedicated central vacuuming systems that discharge outside will normally be permitted by the 
local authority for enforcement of the Clean Air Act. The filtration system and maintenance schedule for these systems may be specified in the permit.

Filter maintenance is critical for vacuum systems because partly or completely blocked filters can substantially compromise system function. HEPA filters on portable or mobile vacuum units should be changed during periodic maintenance. This normally includes pressure drop testing to determine when a filter is clogged and needs to be cleaned or replaced, and aerosol penetration testing to determine that there are no leaks in the HEPA filters. The latter is also normally conducted when a new filter is installed to ensure the unit is correctly positioned and that there is no dust leaking around the filter. (Periodic maintenance is also recommended for fixed systems.)

Mobile or portable vacuum units and other cleaning equipment used in beryllium work areas should be labeled appropriately and should not be used in non-beryllium workplaces. Such equipment contains berylliumcontaminated dust and debris and can be a source of contamination when being emptied or handled outside of beryllium-regulated areas. Therefore, adequate facilities should be available to prevent personnel exposure and dust dispersion while emptying vacuum cleaners and changing HEPA filter.

Use of dry cleaning methods, such as shoveling, sweeping, or brushing, are prohibited because they entrain settled dust into the workroom air. These methods are only acceptable in completely closed systems such as a glove box.

\subsection{Personal Protective Equipment}

\subsubsection{Protective Clothing}

The type of protective clothing (e.g., coveralls, lab coats, or shoe covers) required for beryllium operations should be based on the work conditions and expected contamination levels and documented in site-specific procedures. Typically, a lab coat and gloves are the minimum protection needed. Impermeable gloves should be used to avoid skin contamination; open wounds must be covered. Other protective equipment (face shields, goggles, gloves) should be used as necessary.

Additional protective equipment may be required when the danger of skin or eye exposure to soluble forms of beryllium exists. Skin exposure can lead to allergic sensitization, which can exacerbate pre-existing CBD (Epstein 1991; Rossman and W. Jones-Williams, 1991)-although this has never been properly evaluated. In the absence of data to the contrary, precautions against contact with soluble forms of beryllium are prudent. Normal handling of the insoluble forms of beryllium (e.g., bulk items made of beryllium metal or a beryllium alloy) will not cause skin or eye problems, but there may be activities such as cleanup where the form of beryllium is unknown. For example, soluble beryllium salts may be formed when beryllium metal comes into contact with acid. Furthermore, beryllium prevents the healing of 
wounds. For this reason, dermal as well as inhalation exposure should be considered in the handling of beryllium materials that may enter existing wounds, cause wounds, or otherwise enter the skin. This is particularly relevant in cleanup, maintenance, disposal activities, and in new work procedures where there is the potential for skin exposure to unknown chemical forms of beryllium.

Clean, reusable, or disposable protective clothing should be provided (at least daily) to all employees working in areas where there is the potential for exposure to airborne beryllium at or above established action levels. Reusable clothing is more comfortable but, when contaminated, presents the problem of potential exposure to laundry personnel.

Street clothing is to be removed and protective gear (outer clothing, underwear, and work shoes or booties) donned before entering areas where beryllium concentrations may be above an established action level. This practice will help eliminate the possibility of exposing employees (or their families) to beryllium dust that may get into street clothing. Where this practice was not in place, it has been shown that beryllium released from work clothes by agitation (e.g., laundering) was apparently sufficient to precipitate beryllium disease.

Protective clothing and equipment should be removed in the change room upon leaving the processing area. Such clothing or protective equipment should either be discarded as toxic waste or segregated and properly labeled as berylliumcontaminated laundry, as specified in Section 6.2.4 (Warning Signs and Labels).

\subsubsection{Respiratory Protection}

Respiratory protection is the least desirable method for controlling occupational exposure. Respirators should be used only as a last resort

1. During the time period necessary to install, evaluate, or repair engineering controls.

2. In maintenance and repair activities where engineering controls are not feasible.

3. In other work situations where engineering controls and supplemental work practices are insufficient to reduce exposure to or below the occupational exposure limits.

4. In emergencies.

Employers must comply with OSHA's respirator standard, 29 CFR 1910.134, which covers the respirator program training, medical requirements, and prohibitions among other items. Additional information on respiratory protection can be found in American National Standard Practices for Respiratory Protection (ANSI Z88.2-1991) and Respiratory Protection: A Manual and Guideline (Colton 1991). 
Respirators selected shall be certified by the NIOSH and the Mine Safety and Health Administration in accordance with the guidance provided in this section. Various types of respirators are listed in Table 5-1 on the following page. Half-mask, air-purifying HEPA-filtered-type respirators allow users to enter an area with a beryllium concentration up to $20 \mu \mathrm{g} / \mathrm{m}^{3}$, while the SCBAs provide protection where exposures are in excess of $2,000 \mu \mathrm{g} / \mathrm{m}^{3}$ or unknown. The two extremes of commercially available respirators, when properly fitted and worn correctly, allow workers to be in areas where airborne beryllium concentrations exceed the occupational exposure limit by 10X and over 1,000X. The 10X and 1,000X amounts allowed over the exposure limit are called protection factors, formally defined as "the ratio of the ambient concentration of an airborne substance to the concentration of the substance inside the respirator at the breathing zone of the wearer" (see American National Standard Practices for Respiratory Protection, ANSI Z88.21991). The values given in Table 5-1 are nominal protection factors, which will differ from person to person depending upon the fit of the respirator and the conditions of its use. The actual protection factors are empirically determined for each worker.

Respirators shall be supplied upon request (and at no cost) to all employees who work in beryllium areas where concentrations can exceed the recommended action level $\left(1.0 \mu \mathrm{g} / \mathrm{m}^{3}\right)$. Respirators must be

1. Individually selected and fitted.

2. Conscientiously worn.

3. Regularly maintained.

4. Properly stored.

5. Worn only with medical approval.

6. Used in accordance with ANSI Z88.2-191; 29 CFR 1910.1001, Appendix C; or 29 CFR 1926.58, Appendix C.

The HEPA filters for respirators must be replaced whenever there is an increase in breathing resistance. Employers should maintain an adequate supply of filter elements and make these available to employees on an asneeded basis. Employers should also allow their employees to leave the workplace to wash their faces to avoid potential skin irritation associated with respirator use. 


\section{Table 5-1. Guidance for selecting respirators. (NOTE: respirators listed in in order of increasing degree of protection.)}

\begin{tabular}{|c|c|}
\hline $\begin{array}{l}\text { IF the airborne beryllium } \\
\text { concentration is }\end{array}$ & THEN use \\
\hline $\begin{array}{l}<20 \mu \mathrm{g} / \mathrm{m}^{3} \\
(<10 \times \mathrm{PEL})\end{array}$ & $\begin{array}{l}\text { A half-mask, air-purifying, high-efficiency particulate } \\
\text { air-filtered respirator. }\end{array}$ \\
\hline $\begin{array}{l}<50 \mu \mathrm{g} / \mathrm{m}^{3} \\
(<25 \times \text { PEL })\end{array}$ & $\begin{array}{l}\text { A powered air-purifying, high-efficiency particulate air- } \\
\text { filtered respirator with a loose-fitting hood or helmet, or } \\
\text { A supplied-air respirator with a loose fitting hood or } \\
\text { helmet facepiece operated in the continuous flow mode. }\end{array}$ \\
\hline $\begin{array}{l}<100 \mu \mathrm{g} / \mathrm{m}^{3} \\
(<50 \times \mathrm{PEL})\end{array}$ & $\begin{array}{l}\text { A full-facepiece, air-purifying, high-efficiency } \\
\text { particulate air-filtered respirator, or } \\
\text { A supplied-air respirator with a tight-fitting half-mask } \\
\text { operated in the continuous flow mode, or } \\
\text { A powered air-purifying, high-efficiency particulate air- } \\
\text { filtered respirator with a tight-fitting half-mask. }\end{array}$ \\
\hline $\begin{array}{l}<500 \mu \mathrm{g} / \mathrm{m}^{3} \\
(<250 \times \mathrm{PEL})\end{array}$ & $\begin{array}{l}\text { A powered air-purifying respirator with a tight-fitting, } \\
\text { high-efficiency particulate air-filtered, full facepiece, or } \\
\text { A supplied-air respirator with a tight-fitting full } \\
\text { facepiece operated in the continuous flow mode. }\end{array}$ \\
\hline $\begin{array}{l}<2000 \mu \mathrm{g} / \mathrm{m}^{3} \\
(<1000 \times \text { PEL })\end{array}$ & $\begin{array}{l}\text { A supplied-air respirator with a half-mask or full } \\
\text { facepiece operated in the pressure demand or other } \\
\text { positive-pressure mode. }\end{array}$ \\
\hline $\begin{array}{l}>2000 \mu \mathrm{g} / \mathrm{m}^{3} \text { or unknown } \\
\text { concentrations } \\
(>1000 \mathrm{X} \text { PEL })\end{array}$ & $\begin{array}{l}\text { A self-contained breathing apparatus operated in the } \\
\text { pressure demand or other positive pressure mode, or } \\
\text { A supplied-air respirator with a full facepiece operated in } \\
\text { the pressure demand or other positive pressure mode that } \\
\text { is equipped with an auxiliary escape-type self-contained } \\
\text { breathing apparatus operated in the pressure-demand } \\
\text { mode. }\end{array}$ \\
\hline
\end{tabular}

NOTES: Respirators selected for use at higher concentrations may also be used at lower concentrations; respirators must not, however, be used at concentrations higher than those for which they are approved.

Full facepiece respirators should be worn during operations where air-borne beryllium has the potential to cause irritation to eyes or skin. 


\section{Medical Monitoring}

Respiratory exposure to aerosolized beryllium, in susceptible individuals, causes an immunological reaction that can result in granulomatous scarring of the lung parenchyma, shortness of breath, cough, and ultimately, fatigue, weight loss and respiratory failure (Kriebel 1988; Eisenbud and Lisson 1983; Newman 1989). Medical surveillance to determine the prevalence of chronic beryllium disease has been shown to be a prudent and practical means of identifying work conditions that can cause disease (Kreiss 1989). Medical monitoring that is performed as part of the surveillance can identify persons with early stages of the disease or heightened sensitivity to beryllium exposure, allowing for their removal from further exposure, medical followup, and, if needed, treatment.

Chronic beryllium disease has a delayed onset, from less than a year to more than 30 years (Preuss and Rossman 1991; Kreiss 1993a). Workers who contract the disease should be medically tracked for their entire lifetime after beryllium exposure, if all cases of disease are to be identified and early treatment initiated. CBD is an immunological disease (Newman 1989; Deodhar, 1991) with evidence of genetic predisposition (Richeldi 1993). Therefore, exposure standards developed for the majority of workers may not be sufficient for highly susceptible workers. CBD has been diagnosed in workers with only brief or apparently low-level exposures (Kriess 1993). While a higher prevalence of disease is to be expected among the more highly exposed workers, those with low-level exposures must also be considered for a comprehensive surveillance program.

\subsection{Medical Surveillance Categorized by Exposure}

Medical surveillance can be separated into categories based on known or suspected exposures.

1. High exposure, hence high risk. This category applies to those individuals known to have been or who may be exposed to levels at or near the current 8-hour time-weighted average permissible exposure limit (PEL) of $2 \mu \mathrm{g} / \mathrm{m}^{3}$. To ensure that all employees at risk are covered, a lower level such as an action level or administrative limit is recommended. It is appropriate to include in this category workers who are exposed to beryllium but did not have exposure levels measured.

2. Low exposure. This category applies to beryllium exposures less than the selected control level but greater than the exposure one would receive from the environment.

3. No exposure. This category applies to all employees who have never worked in beryllium areas and therefore were never exposed to beryllium, and to those who have worked in such areas but personal 
monitoring data have indicated that they are not exposed. An attempt should be made to include in this category people who only tour beryllium facilities. If these individuals cannot be prevented from entering the facility, they should be equipped with personal air monitors to provide evidence that they are not exposed to beryllium in order to minimize concern regarding their contracting $\mathrm{CBD}$ in the future.

\subsection{Medical Monitoring for CBD}

There are multiple tests available for screening for CBD, but there is controversy as to which test (and its frequency) should be used in a beryllium surveillance program. In screening for an uncommon disease such as CBD, only very sensitive and specific tests have satisfactory predictive values.

\subsubsection{High-Exposure Workers}

Individuals who work in beryllium areas where there is a potential for high exposure may be monitored periodically. They should have a pre-placement examination followed by periodic examinations at least annually. Termination examinations may also be worthwhile to remind workers of symptoms that warrant medical evaluation for CBD. Medical examinations should include

1. A complete medical and occupational history.

2. A physical examination.

3. A chest x-ray.

4. A vital capacity determination.

5. An LPT.

In addition, the American Thoracic Society Respiratory History should be obtained. All chest $\mathrm{x}$-ray should be read by a " $\mathrm{B}$ " reader trained in the ILO classification system for the identification of pneumoconiosis (ILO 1980). Chest $x$-rays have been shown to have limited effectiveness in identifying CBD (Kreiss 1993a, 1993b), but are useful for documenting the absence of other disease. The minimal data obtained from pulmonary function tests are the forced vital capacity (FVC) and forced expiratory flow at one second $\left(\mathrm{FEV}_{1}\right)$.While this test is not especially useful in identifying early $\mathrm{CBD}$, it can show other pulmonary disease. Both chest $\mathrm{x}$-rays and pulmonary function tests certainly can be abnormal in advanced CBD but are important as a baseline.

Other tests such as carbon monoxide diffusion and pulmonary function repeated as often as every three months using the same spirometer also have been used to detect early disease with some success (Markham, 1991). On the other hand, the lymphocyte proliferation test, which uses beryllium to stimulate lymphocyte cell growth (Be-LPT), has been used to screen peripheral blood and as a diagnostic aid using cells separated from lung 
washings (Newman 1989; Kreiss 1989; Kreiss 1993a; Rossman 1988). Because the Be-LPT has limited application and is difficult and expensive to perform, it is only used in a few laboratories in the United States. It has been used to identify numerous people who are sensitized to beryllium but have few, if any symptoms as well as minimal findings on routine clinical examination. For some of these sensitized people, more detailed clinical followup has resulted in a diagnosis of CBD.

The prevalence of CBD in typical beryllium worker populations is estimated to be approximately two percent (Eisenbud 1983). It is only recently that sufficient data have been gathered to estimate the sensitivity and specificity of the Be-LPT. Thus, we can now recommend use of this test in groups likely to have some prevalence of disease. Estimations of the sensitivity of the Be-LPT have been variable (Stoke, 1991). In one study, as many as $50 \%$ of cases having confirmed, positive peripheral Be-LPTs showed no evidence of CBD, while as many as $30 \%$ of confirmed CBD cases had normal peripheral Be-LPT responses in at least one laboratory when blood samples were simultaneously sent to more than one laboratory. A recent study evaluated all individuals with abnormal chest $\mathrm{x}$-rays. Of 31 with abnormal chest $\mathrm{x}$-rays, four were found to have CBD—three of which had positive peripheral Be-LPTs (Kreiss, 1993a). Five other cases of CBD were found with normal chest $\mathrm{x}$-rays and positive peripheral Be-LPTs.

Pulmonary function testing, chest $\mathrm{x}$-rays, and even symptoms are not good predictors of CBD (Kreiss 1993a). The peripheral blood Be-LPT seems to be good, particularly for sub-clinical cases, but should be regarded with suspicion. For example, a single Be-LPT is not enough to confirm CBD in a person who has been possibly exposed to aerosolized beryllium and has signs or symptoms consistent with the disease. Clinicians should take care that falsepositive Be-LPT tests do not initiate unnecessary clinical evaluations.

Repeated evaluations (every three years recommended) are appropriate for all persons exposed to significant levels of beryllium because of the delay between first exposure and first indication of disease (latency period). This will result in less concerns about false-negative tests, particularly when diagnosing CBD in the very early stages. This recommendation applies only to the asymptomatic exposed worker. An exposed worker with any pulmonary symptoms should be evaluated immediately.

\subsubsection{Low-Exposure Workers}

It is possible for individuals exposed below selected control levels (but above ambient levels) to have some level of risk for CBD. The disease has been identified in persons who have had only brief or occasional exposure to levels that were presumed to be minimal, such as neighborhood cases without secondary exposure from others in the household, secretaries, and security guards (Eisenbud 1883, Kreiss 1993b). While there is no way of knowing for sure whether these individuals had a brief high-level exposure that went undetected, 
a possible explanation may be that they are sensitive to beryllium. Assuming a low prevalence of disease in this low-level exposed population, screening of the entire population is not appropriate nor recommended.

\subsection{Issues}

Some beryllium workers develop persistently abnormal LPT with no evidence of beryllium disease. This may be due to a variable latency period between sensitization and development of disease. The risk of sensitization, however, may be lifelong in beryllium workers. Thus, the natural history of beryllium sensitization after exposure and of beryllium disease after sensitization needs to be defined by a longitudinal study. Similarly, the efficacy of early identification and intervention in reducing the morbidity and mortality of CBD requires a controlled clinical trial.

\section{Waste Management}

Beryllium waste may (or may not) be regulated as a hazardous waste under the RCRA. Where it is regulated, labeling and disposal procedures are required as well as permits for discharges to air and water. The facility's Environmental Section can provide guidance for effectively (and legally) disposing of waste and applicable emissions standards.

Beryllium-contaminated materials including waste, scrap, debris, bags, containers, equipment, or clothing should be disposed of properly. Items for disposal should be placed in impermeable, sealed bags or containers (e.g., drums) that are labeled in accordance with the requirements in 29 CFR 1910.1200. Containment and labeling of beryllium waste should be considered beryllium operations. Thus, employees responsible for such tasks should be trained in the hazards of beryllium. Where beryllium waste is regulated as hazardous waste, RCRA requirements on labeling and disposal must be followed.

\section{Decommissioning and Decontamination Projects}

Decommissioning is the process of decontaminating or dismantling a facility or piece of equipment at the end of its useful life so that it does not present a 
hazard to workers, the public, or the environment. Decommissioning may be initiated to

- Remove beryllium or beryllium-contaminated items from a site. This may include dismantling/decontamination of a berylliumcontaminated building or equipment and removal of contaminated drummed materials.

- Dispose of beryllium-contaminated equipment or facility and beryllium-contaminated waste generated during the project. This waste may meet the definition of a RCRA hazardous waste and, if so, must be disposed of in accordance with strict regulations. Other hazardous components present on surfaces and in the waste generated must also be addressed. Asbestos and PCBs are common toxic materials present in production facilities. Radioactive materials are common cocontaminants at DOE facilities.

- Implement CERCLA removal and remedial actions in order to control a release (or potential for release) of beryllium to the environment in accordance with the requirements of the National Contingency Plan (NCP). Remedial actions may involve stripping beryllium from environmental media in-place, such as soil and groundwater restoration.

- Comply with requirements of a RCRA permit or order.

- Comply with other requirements that characterize beryllium as a secondary hazard (e.g., decommissioning to terminate an Nuclear Regulatory Commission (NRC) license).

Decontamination is the removal or reduction of beryllium from facilities, equipment, soils, or water to achieve the stated release criteria. It may be part of a decommissioning activity or preventive in nature, and may employ both chemical and physical methods to achieve the desired result. These range from simple janitorial-type functions (vacuuming, wiping, mopping) to more sophisticated chemical processes capable of dissolving adherent particles. Decontamination and monitoring methods should be carefully selected to avoid any potential for significant amounts of waste to spread over large areas.

Because of the variety of reasons for decommissioning and the range of facility and equipment types, it is not possible to recommend specific remedial actions. Rather, the steps and considerations to be made during a decommissioning action are presented. More detail about requirements and protocols may be found in the cited references (see DOE Order 5400.4; DOE/EM-0412; DOE/EM-0246, August 1995; DOE/EM, May 22, 1995; 10 CFR 1021; 29 CFR 1910.120; and Kolanz 1996). 


\subsection{Project Planning}

Planning is a key step in a beryllium decommissioning project. It involves individuals from various areas (operations, maintenance, engineering, health, safety, and environment fields, public relations, legal, and finance) and requires the following steps:

1. Evaluate the reason for the decommissioning project, the extent of contamination, potential safety and health hazards involved, the condition of the facility or equipment, operating and land use requirements, and the intended reuse or disposal of equipment and waste materials. This activity requires a site inspection.

2. Clearly establish release criteria for decontamination of equipment, structures, and the environment based on the intended use and disposal plans. Beryllium release criteria for surfaces (equipment and structures) are determined by swipe sampling. Equipment and facilities will have some level of residual beryllium contamination after the decontamination process. Criteria that are set lower than necessary will affect both technical approach and cost. Beryllium release criteria for environmental media will usually follow applicable EPA or state guidelines or negotiated agreements.

3. Determine the remedial alternatives. This step may involve collection of additional information or analyses, and should include a risk assessment or safety analysis for each alternative considered. CERCLA non-time-critical actions (planning horizon of six months or more) are generally preferred to allow adequate integration of owner responsibility, EPA oversight, and state and stakeholder participation, as well as to maximize worker safety, public health, and environmental protection. A written Analysis of Removal Alternatives (ARA) is required for CERCLA projects, but is highly desirable for any project. Major federal projects which do not fall under CERCLA must have a National Environmental Policy Act (NEPA) environmental assessment or impact statement.

4. Establish a project plan to include the project scope, initial budget, phasing, schedule, technical baselines, and responsibilities of each participant. In addition, each project, regardless of size or complexity, should have a formal management and quality control system.

5. Decide whether in-house or an independent contractor(s) will perform the actual decommissioning. Use of contractors can increase cost effectiveness by improving efficiency of specialty operations and eliminating the need for specialized staff training. To ensure selection of a competent, experienced contractor(s), standard competitive bidding procedures should be followed. Additional documentation that might be requested with a beryllium decommissioning/decontamination bid include personal 
protective equipment and respirator program, beryllium training program and medical evaluation, satisfactory experience in decontamination projects, and appropriate insurance without environmental exclusions.

6. Obtain approvals for the planned action, as appropriate. For example, a CERCLA action requires approval of the sampling and analysis plan and a formal community information/input process. At National Priorities List (NPL) sites, the planned remedies and public comments will be documented in a Record of Decision (ROD). It is always useful to designate a spokesperson to notify the community and officials, as appropriate.

7. Prepare the decommissioning plan with engineering involvement. Depending on the circumstances, this may include project specifications, contract documents, the release criteria, the projectspecific health and safety plan, and the waste management plan.

8. Perform a readiness review. The DOE requires such a review be performed by an independent organization prior to actual clean-up work to ensure appropriate procedures are in place, workers are trained, and all necessary preparations have been adequately completed. During complex projects, there may be multiple readiness reviews at different stages of the work.

Once the planning phase has been completed, the following steps are required prior to beginning the decommissioning project:

1. Deactivate the facility or equipment to place it in a safe and stable condition. Deactivation may include draining fuel from equipment, de-energizing non-essential systems, removing uncontaminated stored materials from the project area, and ensuring security of the area.

2. Institute a surveillance and maintenance $(S \& M)$ program prior to and during the decommissioning action to ensure secure containment of beryllium contamination and maintenance of select systems in a shutdown but standby mode. Some minor decontamination and equipment removal may be carried out during S\&M under NEPA categorical exclusion.

If the decommissioning work does not commence soon after deactivation, some facility operations and maintenance activities must be carried out. The possible safety impact of the deactivated status on normal operations should be carefully analyzed.

\subsection{Protecting Personnel}

Code of Federal Regulations, Title 29, Part 1910.120 (HAZWOPER) requires that decontamination procedures be defined in the project-specific Health and 
Safety Plan. Wherever beryllium exposure is anticipated, regulated areas should be established as specified below.

- If the regulated area is inside a building, it should be maintained under negative pressure by a system equipped with a HEPA filter assembly that exhausts filtered air outside the building.

- Regulated areas should be adequately demarcated from the rest of the workplace in a manner that alerts employees to the boundaries of the area. The area may be physically separated from the rest of the facility by taping plastic barriers to access routes, wall openings, windows, and doorways.

- Access to the regulated area should be limited to authorized individuals. A record should be kept of all individuals entering each regulated area including the date, time in/out, and activity performed.

- Change rooms under negative pressure should be provided for removal of beryllium-contaminated clothing. Separate facilities should be provided for employees to change into street clothing and clean protective clothing.

All personnel working in the regulated area should

- Wear Level C protection to minimize exposure to beryllium as a minimum. This includes full-body Tyvek suits (or equivalent) and half-face, air-purifying respirators. More protective respirators are recommended, especially during process ductwork or piping removal.

- Follow a decontamination procedure that includes showering after removal of protective clothing and prior to respirator removal.

- Perform personal air sampling during representative tasks to document the level of beryllium exposure (See Section 4.2.1 for further details).

\subsection{Decontamination of Equipment}

Decontamination of beryllium-contaminated equipment generally involves vacuuming with a HEPA vacuum until no visible dust remains, and wetwiping with water containing a wetting agent or an industrial decontamination soap. The effectiveness of this procedure depends on the beryllium form, particle size, and concentration and the equipment surface characteristics. Often the procedure must be repeated several times to reduce beryllium levels below the release criteria. Depending on the intended use or disposition, both external and internal components of equipment are cleaned.

Items that do not lend themselves to wet-wiping, such as absorptive materials (ceiling tiles) or electrical items (computers), may be HEPA-vacuumed. Contaminated items such as ceiling tiles, carpet, upholstered furniture, light 
fixtures, and ductwork should not be decontaminated for re-use. These should be wiped or vacuum-cleaned and disposed of as waste.

All equipment identified for disposal or re-use should be tagged to indicate beryllium contamination, including potential internal contamination.

Maintenance and repair of potentially contaminated equipment should be performed with controls to prevent exposure and spread of beryllium contamination. Consult the industrial hygiene group before beginning such maintenance work.

\subsection{Decontamination of Beryllium Facilities}

The following guidelines apply when decontaminating beryllium facilities:

1. Start cleaning farthest from the negative pressure exhaust and move toward the system.

2. Clean items to be retained first, then clean those to be disposed of and transfer them to a designated staging area or placed them in a lined and covered roll-off unit. Store items to be retained in a clean storage area.

3. Remove all insulation, ductwork, and ceiling tiles in that order. Use extreme care when removing ductwork: Clean the outside, then remove the ductwork in sections, sealing the ends, and take them to an isolated work area. Vacuum gross quantities of dust, then separate the sections into manageable sizes at joints or by mechanical means and transfer them into disposal containers.

4. Clean permanent walls and structures last. Cleaning should begin from the highest level down to the floor of each room.

5. Encapsulate rough or difficult-to-clean surfaces with paint or other durable coating to prevent the release of beryllium. Label all such surfaces as beryllium-containing surfaces. Use care when encapsulating permanent structural components to ensure fireratings or other building codes are not violated.

6. Demolish identified walls and other structures, if applicable. Use a light spray of water to minimize dust generation.

7. Decontaminate all equipment used in the decontamination process. Properly dispose of all suits and respirator filters at the end of each day. Flush all floor drains.

8. Place beryllium-contaminated waste in plastic-lined trucks or rolloffs for transportation to a disposal facility. Place contaminated water in tanks or tank trucks for disposal, if there is no permit for disposal to the sewage system. 


\subsection{Conclusion of Decommissioning Project}

Final surveys of the decommissioning project should be conducted independent of the in-house group or contractor performing the decommissioning work to demonstrate the release criteria have been achieved. A verification protocol should be implemented that addresses the inspection, sampling and analysis, evaluation, and documentation procedures for verification of beryllium contamination. A certification docket or report should be obtained for the permanent project records.

The decommissioning activity is officially concluded when the clearance criteria have been met in all phases of the project, the waste manifests have been signed and received by the facility owner, all contractor equipment and materials are removed from the facility, and all repairs have been made by the contractor as required. The final report should then be assembled to include the following, as a minimum:

- The history of the facility.

- The purpose of the decommissioning project.

- A description of the facility.

- The status of the pre-decommissioning contamination.

- A description of technical approach.

- The work performed, costs and schedules.

- Waste volumes generated.

- Occupational exposure data.

- Final contamination levels.

- Conclusions and recommendations.

Other items that might be included are photographs before and after the project and the final verification report.

All written materials generated during the project (planning notes, the request for proposal, the bids, change orders, submittals, readiness reviews, air and surface monitoring results, etc.) should be maintained in a permanent project file.

\subsection{Post-Decommissioning Action}

Remedial actions such as those listed below may be required after decommissioning a facility or equipment:

- Site restoration is often not an objective of the decommissioning plan, but may require significant effort and resources. Sometimes equipment and buildings can be put to new use. Land is more commonly restored compared to buildings. 
- Long-term surveillance and maintenance may be necessary (e.g., when entombment of beryllium-contaminated items was selected as the remedial action option).

- Efforts may shift from the decommissioning action to a site remediation action, such as soil or groundwater cleanup.

- An administrative action such as transfer of decontaminated property to new owners may be required.

\section{Facility Design}

This section describes aspects of beryllium exposure control required when designing a facility for beryllium operations.

A facility that houses beryllium operations should be designed with extra features and flexibility. The basic conceptual design should emulate the cleanliness objectives of a surgical operating room. Following are basic recommendations for a facility specifically designed for beryllium operations.

Building Layout. The building layout should have the following features:

- Access control. Access to the facility should be gained only through a locker room so that there is no mingling of employees' street clothing and work clothing. This approach offers the greatest personal protection to workers and subsequent personal contacts (e.g., co-workers outside the facility, family members, and friends) and minimizes liability from potential secondary exposures to persons not directly associated with the employer's operations. Badge readers can be used to control access to the facility and for accountability should evacuation be necessary.

- Zones for operations, contamination reduction, and support areas. Facilities should allow for clear progression from locations of contamination to areas that are relatively free of contamination. Light locks should be installed between operations and support zones. The layout of the contamination reduction zone should include sinks for washing hands, face, and respirators; a physical barrier separating the support zone from the contamination reduction zone; locations for contaminated personal protective equipment containers; separate areas for storing work shoes, sameday-use coveralls and respirators; and an area (on the cleaner side entrance to the contamination reduction zone) for distributing industrial hygiene sampling equipment.

The support zone should include a shower and locker room to allow for segregation of work clothing from street clothing and 
personal belongings. The shower should be separate from the personal locker area and should contain restrooms, sinks, containers for worn modesty garments, benches, and storage for towels. The locker room used to store street clothing have a sink on outer part of the room. Storage for clean work clothing should be located near the personal street clothing lockers.

Compartmentalization of operations with varying degree of exposure potential. This can be achieved by having a central hall with light locks to separate operational areas from the hall and thereby eliminate exposure to others not involved in the activity.

- Decontamination bay for personnel. A personal decontamination bay should be located in the operations area. This bay should differ from an emergency shower. It should allow for hot and cold potable water, privacy, and a storage area for towels and should drain to the exterior of the facility.

- Transition zone for removal of materials/equipment. The facility should contain an area where materials can be transitioned out of the facility, a room for decontaminating materials leaving the facility, and storage and work areas for as many facility and equipment maintenance activities as reasonable. It should also contain all the tools and equipment necessary to perform maintenance activities.

- Janitorial closets or storage areas for operations areas and support areas. Routine housekeeping is an important part of contamination control. Separate janitors closets should be provided for storage of cleaning supplies and equipment to reduce the potential spread of contamination.

- Isolation areas for non-beryllium related equipment. Care should be taken in designing the layout of the facility to keep equipment such as water pumps, cooling water systems, and compressors out of operations areas so that maintenance work does not include beryllium contamination or exposure hazards.

Other design features could include

- A supplied air-breathing system for non-routine work.

- Smooth surfaces on walls, floors, and ceilings to aid in cleaning and to prevent dust accumulation.

- False ceilings (drywall type) in areas where there is a potential for higher contamination. This will reduce dust accumulation and cleaning burden.

- A communications system with evacuation alarms in the event of a partial or total ventilation system shutdown. 
- In-house or onsite laundry facility located on either side of the contamination reduction and support zones.

- In-house or onsite industrial hygiene analytical laboratory to provide for quick turn-around of samples. This laboratory should be located in a manner such that it would be easy to submit samples and limit the potential for sample contamination.

- An in-house video conference center and cameras to reduce the number of visitors and contractors who may have a need to enter the facility.

- A water treatment facility or contaminated water storage area, including sampling locations.

- A paperless, computerized system for storage and transfer of information. This will eliminate the transfer of contamination through paper.

- A receiving/shipping area that is locked from exterior access and segregated from the facility by a light lock.

- An emergency cooling water system for equipment such as furnaces in case of power outage.

\section{References}

ACGIH, American Conference of Governmental Industrial Hygienists. Industrial Ventilation: A Manual of Recommended Practice. 22nd Edition. Cincinnati, OH: ACGIH; 1995.

ACGIH, American Conference of Governmental Industrial Hygienists. 1996 TLVs and BEIs Threshold Limit Values for Chemical Substances and Physical Agents and Biological Exposure Indices. Cincinnati, OH: ACGIH; 1996a.

ACGIH, American Conference of Governmental Industrial Hygienists.

Documentation of the Threshold Limit Values and Biological Exposure Indices. Sixth Edition. Cincinnati, OH: ACGIH; 1996b.

American National Standards Institute. Acceptable concentrations of beryllium and beryllium compounds. New York: ANSI; ANSI Z37.29; 1970.

American National Standards Institute. American National Standard Practices for Respiratory Protection. New York: ANSI; ANSI Z88.2-1991; 1991.

ATSDR, Agency for Toxic Substances and Disease Registry, Public Health Service. Toxicological Profile for Beryllium. Washington, DC: U.S. Department of Health and Human Services; ATSDR/TP-92/04; 1993.

Barna, B. P.; Deodhar, S. D.; Chiang, T.; Gautam, S.; Edinger, M. Experimental Beryllium-Induced Lung Disease. Differences in Immunologic 
Responses to Beryllium Compounds in Strains 2 and 13 Guinea Pigs. Int. Archs. Allergy Appl. Immunol. 73:42-48; 1984.

BISAC, Beryllium Industry Scientific Advisory Committee. Is Beryllium Carcinogenic in Humans? J. Occup. Env. Med. 39(3):205-208; 1997.

Caplan, K.J. The Significance of Wipe Samples. Am. Ind. Hyg. Assoc. J. 54:7075; 1993.

Code of Federal Regulations. DOE National Environmental Policy Act Implementing Procedures. Washington, DC: U.S. Government Printing Office; Title 10, Part 1021.

Code of Federal Regulations. OSHA Hazardous Waste Operations and Emergency Response. Washington, DC: U.S. Government Printing Office; Title 29, Part 1910.120.

Clarke, S. M. A Novel Enzyme-Linked-Immunosorbent-Assay (ELISA) for the Detection of Beryllium Antibodies. J. Immunol. Methods. 137:65-72; 1991.

Clarke, S. M.; Thurlow, S. M.; Hilmas, D. E. Occupational Beryllium Exposure/ Recovery Monitored by Beryllium Antibody Assay: Six Year Case Study. The Toxicologist. 13:440(Abstract); 1993.

Colton, C. E.; Birkner, L. R.; Brosseau, L. M., eds. Respiratory Protection: A Manual and Guideline. Second Edition. Akron, OH: American Industrial Hygiene Association; 1991.

Deodhar, S. D.; Barna, B. P. Immune Mechanisms in Beryllium Lung Disease. Cleve. Clin. J. Med. 58:157-160; 1991.

Eisenbud, M. Origins of the Standards for Control of Beryllium Disease (19471949). Environ. Res. 27:79-88; 1982.

Eisenbud, M.; Lisson, J. Epidemiological Aspects of Beryllium-Induced Nonmalignant Lung Disease: A 30-Year Update. J. Occup. Med. 25:196202; 1983.

Eisenbud, M. Health Problems in the Beryllium Industry. In: An Environmental Odyssey: People, Pollution, Politics in the Life of a Practical Scientist. Seattle, WA: University of Washington Press; 1990:48-54.

Epstein, W. L. Cutaneous Effects of Beryllium. In Rossman, M. D.;

Preuss, O. P.; Powers, M. B. Beryllium, Biomedical and Environmental Aspects. Baltimore, MD: Williams and Wilkins; 1991:113-119.

Finch, G. L.; Hoover, M. D.; Hahn, F. F.; Nikula, K. J.; Belinsky, S. A.; Haley, P. J.; Griffith, W. C. Animal Models of Beryllium-Induced Lung Disease. Environ. Hlth. Perspect. 104(Suppl. 5):973-979; 1996.

Freiman, D. G.; Hardy, H. L. Beryllium Disease: The Relation of Pulmonary Pathology to Clinical Course and Prognosis Based on a Study of 130 Cases from the U.S. Beryllium Case Registry. Hum. Pathol. 1:25-44; 1970. 
Hall, R. H.; Scott, J. K.; Laskin, S.; Stroud, C. A.; Stokinger, H. E. Acute Toxicity of Inhaled Beryllium. Observations Correlating Toxicity with the Physicochemical Properties of Beryllium Oxide Dust. Arch. Ind. Hyg. Occup. Med. 2:25-48; 1950.

Hardy, H. L.; Tabershaw, I. R. Delayed Chemical Pneumonitis Occurring in Workers Exposed to Beryllium Compounds. J. Ind. Hyg. Toxicol. 28:197$211 ; 1946$.

Hawkins, N. C., Norwood, S. K.; Rock, J. C. A Strategy for Occupational Exposure Assessment. Fairfax, VA: American Industrial Hygiene Association; 1991.

HSE, Toxicity Review 27: Triglycidyl isocyanurate, Beryllium and beryllium compounds. Health and Safety Executive. Sheffield, United Kingdom: 1992.

Huang, H.; Meyer, K. C.; Kubai, L.; Auerbach, R. An Immune Model of Beryllium-Induced Pulmonary Granulomata in Mice: Histopathology, Immune Reactivity, and Flow-Cytometric Analysis of Bronchoalveolar Lavage-Derived Cells. Lab Invest. 67:138-146; 1992.

International Agency for Research on Cancer. Monographs on the Evaluation of Carcinogenic Risks to Humans: Vol 58. Beryllium, Cadmium, Mercury, and Exposures in the Glass Manufacturing Industry. Lyon, France: World Health Organization; 1993.

International Labor Organization. Guidelines for the use of ILO international classification of radiographs of pneumoconioses. Geneva, Switzerland: ILO; Occupational Safety and Health Series No. 22 (Rev):1980.

Infante, P. F.; Wagoner, J. K.; Sprince, N. L. Mortality Patterns from Lung Cancer and Non-neoplastic Respiratory Disease among White Males in the Beryllium Case Registry. Environ. Res. 21:35-43; 1980.

Klingner, T.D.; McCorkle, T. The Application and Significance of Wipe Samples. Am. Ind. Hyg. Assoc. J. 55:251-254; 1994.

Kolanz, M. E. Sample "Request for Quotation" for cleaning and decontamination of a beryllium facility, Brush Wellman Inc., Cleveland, OH, February, 7, 1996.

Kolanz, M. E. Comments of Brush Wellman, Inc. on the Department of Energy's Notice Requesting Information Relative to Control of Occupational Exposure to Beryllium in DOE Facilities. Cleveland, $\mathrm{OH}$ : Brush Wellman, Inc.; 1997.

Kreiss, K.; Newman, L. S.; Mroz, M. M.; Campbell, P. A. Screening Blood Test Identifies Subclinical Beryllium Disease. J. Occup. Med. 31:603-608; 1989.

Kreiss, K.; Mroz, M. M.; Zhen, B.; Martyny, J. W; Newman, L. S. Epidemiology of Beryllium Sensitization and Disease in Nuclear Workers. Am. Rev. Resp. Dis. 148:985-991; 1993a. 
Kreiss, K.; Wasserman, S.; Mroz, M. M.; Newman, L. S. Beryllium Disease Screening in the Ceramics Industry: Blood Lymphocyte Performance and Exposure-disease relations. J. Occup. Med.; 35:267-274; 1993b.

Kreiss, K.; Mroz, M. M.; Newman, L. S.; Martyny, J.; Zhen, B. Matching Risk of Beryllium Disease and Sensitization with Median Exposures Below 2 $\mu \mathrm{g} / \mathrm{m}^{3}$. Am. J. Ind. Med. 30:16-25; 1996.

Kriebel, D.; Brain, J. D.; Sprince, N. L.; Kazemi, H. The Pulmonary Toxicity of Beryllium. Am. Rev. Respir. Dis. 137:464-473; 1988.

Levin, L. Letter to the Editor (in response to Hoover, M. D.; Finch, G. L. Release of Aerosols during Milling of Metal and Beryllium Alloys.) Appl. Occup. Environ. Hyg. 6:567; 1991.

Lichtenwalner, C.P. Evaluation of Wipe Sampling Procedures and Elemental Surface Contamination. Am. Ind. Hyg. Assoc. J. 53:657-659; 1992.

MacMahon, B. The Epidemiological Evidence on the Carcinogenicity of Beryllium in Humans. J. Occup. Med. 36(1):15-24; 1994.

Mancuso, T. Mortality Study of Beryllium Industry Workers' Occupational Lung Cancer. Environ. Res. 21:48-55; 1980.

Markham, T. N. Medical examination programs. In Rossman, M. D.; Preuss, O. P.; Powers, M. B., eds. Beryllium: Biomedical and Environmental Aspects. Baltimore, MD: Williams \& Wilkins; 1991:185-192.

Meyer, K. C. Beryllium and Lung Disease. Chest. 106:942-946; 1994.

Mitchell, R.N.; Eutsler, B. C. A Study of Beryllium Surface Contamination and Resuspension. In B.R. Fish, Editor, Symposium on Surface Contamination Gatlinburg, TN, June 1964. Elmsford, NY: Pergamon Press; 1966:349-352.

Newman, L. S.; Kreiss, K.; King, T. E., Jr.; Seay, S.: Campbell, P. A. Pathologic and Immunologic Alterations in Early Stages of Beryllium Disease. Am. Rev. Respir. Dis.; 139:1479-1486; 1989.

Newman, L. S.; Kreiss, K. Nonoccupational Beryllium Disease Masquerading as Sarcoidosis: Identification by Blood Lymphocyte Proliferative Response to Beryllium. Am. Rev. Respir. Dis. 145:1212-1214; 1992.

NIOSH, National Institute for Occupational Safety and Health. Occupational Exposure to Beryllium (Criteria for a Recommended Standard). Rockville, MD: U.S. Department of Health, Education, and Welfare; NIOSH-TR-003-72; PB 210-806; 1972.

NIOSH, National Institute of Occupational Safety and Health. Public Hearing on the Occupational Standard for Beryllium. Cincinnati, OH: U.S. Department of Health, Education, and Welfare; NIOSH-PB83-182378; 1977. 
NIOSH, National Institute of Occupational Safety and Health. Health Hazard Evaluation Determination. Report No. 78-028-480. Persolite Products Inc.: Florence, Colorado. Cincinnati, OH: U.S. Department of Health, Education and Welfare; NIOSH-TR-HHE-78-028-480; 1978.

$\mathrm{NIOSH}$, National Institute for Occupational Safety and Health. NIOSH Manual of Analytical Methods. Method 7102: Beryllium and compounds, as Be. Cincinnati, OH: U.S. Department of Health and Human Services; 1987.

Preuss, O. P. Assessment of Risk Potential. In: Rossman, M. D.; Preuss, O. P.; Powers, M. B., eds. Beryllium: Biomedical and Environmental Aspects. Baltimore, MD: Williams and Wilkins; 1991:263-273.

Preuss, O. P.; Rossman, M. D. Clinical Picture and Nonimmunological Laboratory Findings in Chronic Beryllium Disease. In Rossman, M. D.; Preuss, O. P.; Powers, M. B., eds. Beryllium: Biomedical and Environmental Aspects. Baltimore, MD: Williams \& Wilkins, 1991:133-140.

Reeves, A. L. Toxicodynamics. In: Rossman, M. D.; Preuss, O. P.;

Powers, M. B., eds. Beryllium: Biomedical and Environmental Aspects. Baltimore, MD: Williams \& Wilkins; 1991a:87-93.

Reeves, A. L. Toxicokinetics. In: Rossman, M. D.; Preuss, O. P.; Powers, M. B., eds. Beryllium: Biomedical and Environmental Aspects. Baltimore, MD: Williams \& Wilkins; 1991b:77-86.

Richeldi, L.; Sorrentino, R.; Saltini, C. HLA-DPB1 Glutamate 69: A Genetic Marker of Beryllium Disease. Science. 262:242-244; 1993.

Ridenour, P. K.; Preuss, O. P. Acute Pulmonary Beryllium Disease. In: Rossman, M. D.; Preuss, O. P.; Powers, M. B., eds. Beryllium: Biomedical and Environmental Aspects. Baltimore, MD: Williams \& Wilkins; 1991:103-112.

Rossman, M. D.; Kern, J. A.; Elias, J. A. et al. Proliferative response of bronchoalveolar lymphocytes to beryllium: a test for chronic beryllium disease. Ann. Intern. Med. 108:687-693; 1988.

Rossman, M. D.; Preuss, O. P.; Powers, M.B., eds. Beryllium: Biomedical and Environmental Aspects. Baltimore, MD: Williams \& Wilkins; 1991.

Rossman, M. D.; Jones-Williams, M. Immunopathogenesis of Chronic Beryllium Disease. In Rossman, M. D.; Preuss, O. P.; Powers, M. B. Beryllium, Biomedical and Environmental Aspects. Baltimore, MD: Williams and Wilkins; 1991:121-132.

Rossman, M.D. Chronic Beryllium Disease Diagnosis and Management. Environmental Health Perspectives. 104(S5):945-947; 1996.

Stange, A. W.; Hilmas, D. E.; Furman, F. J. Possible Health Risks from Low Level Exposure to Beryllium. Toxicology. 111:213-224; 1996. 
Steenland, K.; Ward, E. Lung Cancer Incidence Among Patients With Beryllium Disease: A Cohort Mortality Study. J. Natl. Cancer Inst. 83:1380-1385; 1991.

Sterner, J. H.; Eisenbud, M. Epidemiology of Beryllium Intoxication. Arch. Ind. Hyg. Occup. Med. 4:123-151; 1951.

Stokes, R. F.; Rossman, M. D. Blood cell proliferation response to beryllium: analysis by receiver-operating characteristics. J. Occup. Med. 33:23-28; 1991.

U.S. Department of Energy. Comprehensive Environmental Response, Compensation, and Liability Act (CERCLA) Requirements. Washington, DC: DOE; DOE Order 5400.4. 1989.

U.S. Department of Energy. Decommissioning Handbook. Washington, DC: DOE; DOE/EM-0412; March 1992.

U.S. Department of Energy. Decommissioning Manual. Washington, DC: DOE; DOE/EM-0246; August 1995.

U.S. Department of Energy. Environmental Restoration Program Decommissioning Implementation Guide. Washington, DC: DOE; DOE/EM; May 22, 1995.

U.S. Department of Labor. OSHA Technical Manual, Fourth Edition. Washington, DC: Government Institutes, Inc. 1996.

U.S. Environmental Protection Agency. Health Assessment Document for Beryllium. Washington, DC: EPA; EPA/600/8-84/ 026F; 1987.

Vainio, H.; Rice, J. M. Editorial: Beryllium Revisited. J. Occup. Env. Med. 39(3):203; 1997.

Van Ordstrand, H. S.; Hughes, R.; Carmody, M. G. Chemical Pneumonia in Workers Extracting Beryllium Oxide: Report of Three Cases. Cleve. Clin. J. Med. 10:10-18; 1943.

Votto, J. J.; Barton, R. W.; Gionfriddo, M. A.; Cole, S. R.; McCormick, J. R.; Thrall, R. S. A Model of Pulmonary Granulomata Induced by Beryllium Sulfate in the Rat. Sarcoidosis. 4:71-76; 1987.

Wagoner, J. K.; Infante, P. F.; Bayliss, D. L. Beryllium: An Etiologic Agent in the Induction of Lung Cancer, Non-neoplastic Respiratory Disease, and Heart Disease Among Industrially Exposed Workers. Environ. Res. 21:15-34; 1980.

Ward, E.; Okun, A.; Ruder, A.; Fingerhut, M.; Steenland, K. A Mortality Study of Workers at Seven Beryllium Processing Plants. Am. J. Ind. Med. 22:885-904; 1992.

World Health Organization. Environmental Health Criteria 106: Beryllium. Geneva, Switzerland: WHO; 1990. 


\section{Appendix A}

\section{Details of EPA Regulations}

\section{A.1 Air Programs}

In 40 CFR 51.166(b)(23)(i), 52.21(b)(23)(i), "Prevention of Significant Deterioration of Air Quality," the EPA defines "significant" in reference to a net emissions increase or the potential of a source to emit beryllium as the rate of emissions that would equal or exceed 0.0004 tons/year.

40 CFR 61 contains the EPA's National Emission Standard for Beryllium. This standard is applicable to extraction plants, ceramic plants, foundries, incinerators, and propellant plants that process beryllium ore, beryllium, beryllium oxide, beryllium alloys, or beryllium-containing waste; and to machine shops that process beryllium, beryllium oxides, or any alloy when such alloy contains more than $5 \%$ beryllium by weight. The standard states

Emissions to the atmosphere from stationary sources shall not exceed 10 grams of beryllium over a 24-hour period, except that an owner or operator may request approval to meet an ambient concentration limit on beryllium in the vicinity of the stationary source of $0.01 \mu \mathrm{g} / \mathrm{m}^{3}$, averaged over a 30-day period.

The standard also contains controls for beryllium emissions from rocket firing and sampling and analysis methods in Appendix A, Method 103: Beryllium Screening Method, and Method 104: Determination of Beryllium Emissions From Stationary Sources. Appendix A also mentions beryllium in the National Emission Standards for Hazardous Air Pollutants (NESHAPs) regulation in 40 CFR 63.74(f).

\section{A.2 Water Programs}

Beryllium compounds designated as hazardous substances can be found in 40 CFR 116.4 under "Federal Water Pollution Control Act." Spills of these materials are subject to the reportable quantities (RQ) requirements in 40 CFR 117.3.

\begin{tabular}{|l|c|c|}
\hline \multicolumn{1}{|c|}{ Table A-1. Reportable quantities of hazardous substances. } \\
\hline Material & CAS number & RQ in lb (kilograms) \\
\hline Beryllium chloride & 7787475 & $1(0.454)$ \\
\hline Beryllium fluoride & 7787497 & $1(0.454)$ \\
\hline Beryllium nitrate & 7787555 & $1(0.454)$ \\
\hline
\end{tabular}


40 CFR 122 and its Appendix D "National Pollutant Discharge Elimination System" contain permit application testing requirements for beryllium.

40 CFR 136.3 contains test procedures for analyzing beryllium pollutants. Appendix $\mathrm{C}$ of this regulation contains an procedure for analyzing beryllium in drinking water, surface water, and domestic and industrial waste waters.

40 CFR 141.23 “National Primary Drinking Water Regulations," contains a maximum beryllium contaminant level of $0.004 \mathrm{mg} / 1$ and provides chemical sampling and analytical requirements. Under "Public Notification" in 40 CFR 141.32(e)(54), the regulations state:

Beryllium. The [EPA] sets drinking water standards and has determined that beryllium is a health concern at certain levels of exposure. This inorganic metal occurs naturally in soils, ground water and surface waters and is often used in electrical equipment and electrical components. It generally gets into water from runoff from mining operations, discharge from processing plants and improper waste disposal. Beryllium compounds have been associated with damage to the bones and lungs and induction of cancer in laboratory animals such as rats and mice when the animals are exposed at high levels over their lifetimes. There is limited evidence to suggest that beryllium may pose a cancer risk via drinking water exposure. Therefore, EPA based the health assessment on noncancer effects with an extra uncertainty factor to account for possible carcinogenicity. Chemicals that cause cancer in laboratory animals also may increase the risk of cancer in humans who are exposed over long periods of time. EPA has set the drinking water standard for beryllium at 0.004 part per million (ppm) to protect against the risk of these adverse health effects. Drinking water which meets the EPA standard is associated with little to none of this risk and should be considered safe with respect to beryllium.

40 CFR 141.51 establishes a maximum contaminant level of $0.004 \mathrm{mg} / 1$ for beryllium. The level is also set at $0.004 \mathrm{mg} / 1$ in 40 CFR 141.62, "National Revised Primary Drinking Water Regulations: Maximum Contaminant Level." In 40 CFR 141.62 and 40 CFR 162.62, establishes activated alumina, coagulation/filtration, ion exchange, lime softening, and reverse osmosis as the best technologies for achieving compliance with these specified limits

40 CFR 401.15, “Toxic Pollutant Effluent Guidelines and Standards," identifies beryllium and its compounds.

40 CFR 403, "General Pretreatment Regulations for Existing and New Sources of Pollution," identifies firing of sewage sludge in a sewage sludge incinerator as an authorized disposal practice. 
40 CFR 421.1, "Nonferrous Metals Manufacturing Point Source Category," contains extensive requirements for beryllium effluents, stating

This part applies to facilities producing primary metals from ore concentrates and recovering secondary metals from recycle wastes which discharge or may discharge pollutants to waters of the United States or which introduce or may introduce pollutants into a publicly owned treatment works. The applicability of this part to alloying or casting of nonferrous metals is limited to alloying or casting of hot metal directly from the nonferrous metals manufacturing process without cooling. Remelting followed by alloying or cooling is included in the aluminum forming, nonferrous metals forming, or metal molding and casting point source categories.

40 CFR 421, subpart o, contains the Primary Beryllium Subcategory. 40 CFR 421.3 gives monitoring and reporting requirements. Requirements for beryllium can be found in

- 40 CFR 421.150, "Applicability: Description of the primary beryllium subcategory."

- 40 CFR 421.151, "Specialized definitions."

- 40 CFR 421.152, "Effluent limitations guidelines representing the degree of effluent reduction attainable by the application of the best practicable control technology currently available."

- 40 CFR 421.153, "Effluent limitations guidelines representing the degree of effluent reduction attainable by the application of the best available technology economically achievable."

- 40 CFR 421.154, Standards of performance for new sources."

- 40 CFR 421.156, "Pretreatment standards for new sources."

40 CFR 423, "Steam Electric Power Generating Point Source," lists beryllium as a priority pollutant.

40 CFR 464 contains requirements for metal molding and casting point sources; 40 CFR 464.02. covers copper casting and copper beryllium alloys. Similar beryllium references are contained in 40 CFR 468.20 for the Beryllium Copper Forming Subcategory.

The atmospheric emission standards in 40 CFR 61 are also cited in EPA's standards (40 CFR 503.40) for the incineration of sewage sludge.

\section{A.3 Resource Conservation and Recovery Act (RCRA) Regulations}

Under the RCRA Criteria for Municipal Solid Waste Landfills (40 CFR 258.54(a), Appendix I and 40 CFR 258.55(b) Appendix II), beryllium is listed as a substance for which ground water detection monitoring is required. Test 
methods are cited in 40 CFR 260.11(a). Under 40 CFR 261.3(c)(2)(ii)(B) and 40 CFR 261.33(e), beryllium is identified as a hazardous waste constituent. (See also 40 CFR 261, Appendix VIII). Beryllium wastes are also referenced in Appendix IX. Issues regarding beryllium wastes incompatibilities with other materials are addressed in Appendix V of 40 CFR 264, "Standards for Owners and Operators of Hazardous Waste Treatment, Storage, and Disposal Facilities," and in Appendix V of 40 CFR 265, "Interim Status Standards for Owners and Operators of Hazardous Waste Treatment, Storage, and Disposal Facilities." Groundwater monitoring for beryllium is cited in Appendix IX of 40 CFR 264.

Limits on the amount of beryllium wastes that may be treated as hazardous waste and burned in boilers and industrial furnaces can be found in 40 CFR 266.102(e)(6)(ii), 40 CFR 266.103(b)(2)(ii)(A), 40 CFR 266.103(b)(2)(iii), 40 CFR 266.103(b)(2)(iv)(A), 40 CFR 266.103(b)(2)(v), 40 CFR 266.103(b)(5)(ii), 40 CFR 266.103(c)(4)(iv)(C), 40 CFR 266.106(b)(2)(i), 40 CFR 266.106(c)(2), 40 CFR 266.106(d)(3), and in Appendices I, V, and VII of 40 CFR 266. Appendix IX in 40 CFR 266 describes the stack sampling method, procedures for determining default values for air pollution control system removal efficiencies and default values for partitioning of metals, ash, and total chloride/chlorine, and an alternative methodology for implementing metals controls. Beryllium wastes are referenced in all of these regulations as well as in 40 CFR 261.33(e), 40 CFR 268.41(a); 40 CFR 268.42(a)(3); 40 CFR 268.46, Table 1; 40 CFR 270.66(c)(1)(i); and 40 CFR 270.66(f)(1).

\section{A.4 Superfund Amendments and Reauthorization Act (SARA) Regulations}

Table A-2 on the following page lists hazardous substances and reportable quantities. It was reproduced from Table 302.4 in 40 CFR 302.4(b).

\section{A.5 National Emission Standard for Beryllium, 40 CFR 61, Subpart C}

61.30 The provisions of this section are applicable to the following stationary sources:

61.30(a) Extraction plants, ceramic plants, foundries, incinerators, and propellant plants which process beryllium ore, beryllium, beryllium oxide, beryllium alloys, or beryllium-containing waste.

61.30(b) Machine shops which process beryllium, beryllium oxides, or any alloy when such alloy contains more than 5 percent beryllium by weight. 


\begin{tabular}{|c|c|c|c|c|c|c|c|}
\hline $\begin{array}{l}\text { Hazardous } \\
\text { substance }\end{array}$ & CAS number & $\begin{array}{l}\text { Regulatory } \\
\text { synonyms }\end{array}$ & $\begin{array}{l}\text { Statutory } \\
\text { RQ }\end{array}$ & Code & $\begin{array}{c}\text { RCRA } \\
\text { waste \# }\end{array}$ & $\begin{array}{l}\text { Final RQ } \\
\text { category }\end{array}$ & $\begin{array}{l}\text { RQ in } \mathrm{lb} \\
(\mathrm{kg})\end{array}$ \\
\hline Beryllium & $7440-41-7$ & $\begin{array}{l}\text { Beryllium } \\
\text { dust }\end{array}$ & $1^{*}$ & $2,3,4$ & P015 & A & $10(4.54)$ \\
\hline $\begin{array}{l}\text { Beryllium and } \\
\text { its compounds }\end{array}$ & $\mathrm{N} / \mathrm{A}$ & & $1^{*}$ & 2,3 & & & \\
\hline $\begin{array}{l}\text { Beryllium } \\
\text { chloride }\end{array}$ & $7787-47-5$ & & 5000 & 1 & & $x$ & $1(0.454)$ \\
\hline $\begin{array}{l}\text { Beryllium } \\
\text { powder }\end{array}$ & $7440-41-7$ & Beryllium & $1^{*}$ & $2,3,4$ & P015 & A & $10(4.54)$ \\
\hline $\begin{array}{l}\text { Beryllium } \\
\text { fluoride }\end{array}$ & $7787-49-7$ & & 5000 & 1 & & $X$ & $1(0.454)$ \\
\hline $\begin{array}{l}\text { Beryllium } \\
\text { nitrate }\end{array}$ & $13597-99-4$ & & 5000 & 1 & & $X$ & $1(0.454)$ \\
\hline \multicolumn{8}{|c|}{$\begin{array}{l}\text { * Indicates that the 1-pound RQ is a CERCLA statutory RQ and that the RQ is subject to change when the } \\
\text { assessment of potential carcinogenicity is completed. The Agency may adjust the statutory RQ for this } \\
\text { hazardous substance in a future rulemaking; until then the statutory RQ applies. }\end{array}$} \\
\hline \multicolumn{8}{|c|}{$\begin{array}{l}\text { In } 40 \text { CFR } 302.6(\mathrm{~d}) \text {, the regulations indicate that notification of the release of an RQ of solid particles of É } \\
\text { beryllium É is not required if the mean diameter of the particles released is larger than } 100 \mathrm{~mm}(0.004 \mathrm{in} \text {.). }\end{array}$} \\
\hline
\end{tabular}

61.31 Definitions. Terms used in this subpart are defined in the act, in subpart A of this part, or in this section as follows:

61.31(a) Beryllium means the element beryllium. Where weights or concentrations are specified, such weights or concentrations apply to beryllium only, excluding the weight or concentration of any associated elements.

61.31(b) Extraction plant means a facility chemically processing beryllium ore to beryllium metal, alloy, or oxide, or performing any of the intermediate steps in these processes.

61.31(c) Beryllium ore means any naturally occurring material mined or gathered for its beryllium content.

61.31(d) Machine shop means a facility performing cutting, grinding, turning, honing, milling, deburring, lapping, electrochemical machining, etching, or other similar operations.

61.31(e) Ceramic plant means a manufacturing plant producing ceramic items.

61.31(f) Foundry means a facility engaged in the melting or casting of beryllium metal or alloy. 
61.31(g) Beryllium-containing waste means material contaminated with beryllium and/or beryllium compounds used or generated during any process or operation performed by a source subject to this subpart.

61.31(h) Incinerator means any furnace used in the process of burning waste for the primary purpose of reducing the volume of the waste by removing combustible matter.

61.31(i) Propellant means a fuel and oxidizer physically or chemically combined which undergoes combustion to provide rocket propulsion.

61.31(j) Beryllium alloy means any metal to which beryllium has been added in order to increase its beryllium content and which contains more than 0.1 percent beryllium by weight.

61.31(k) Propellant plant means any facility engaged in the mixing, casting, or machining of propellant.

\subsection{Emission standard}

(a) Emissions to the atmosphere from stationary sources subject to the provisions of this subpart shall not exceed 10 grams of beryllium over a 24-hour period, except as provided in paragraph (b) of this section.

(b) Rather than meet the requirement of paragraph (a) of this section, an owner or operator may request approval from the Administrator to meet an ambient concentration limit on beryllium in the vicinity of the stationary source of $0.01 \mu \mathrm{g} / \mathrm{m}^{3}$, averaged over a 30-day period.

(1) Approval of such requests may be granted by the Administrator provided that:

(I) At least 3 years of data is available which in the judgment of the Administrator demonstrates that the future ambient concentrations of beryllium in the vicinity of the stationary source will not exceed $0.01 \mu \mathrm{g} / \mathrm{m}^{3}$, averaged over a 30-day period. Such 3-year period shall be the 3 years ending 30 days before the effective date of this standard.

(ii) The owner or operator requests such approval in writing within 30 days after the effective date of this standard.

(iii) The owner or operator submits a report to the Administrator within 45 days after the effective date of this standard which report includes the following information:

(a) Description of sampling method including the method and frequency of calibration.

(b) Method of sample analysis. 
(c) Averaging technique for determining 30-day average concentrations.

(d) Number, identity, and location (address, coordinates, or distance and heading from plant) of sampling sites.

(e) Ground elevations and height above ground of sampling inlets.

(f) Plant and sampling area plots showing emission points and sampling sites. Topographic features significantly affecting dispersion including plant building heights and locations shall be included.

(g) Information necessary for estimating dispersion including stack height, inside diameter, exit gas temperature, exit velocity or flow rate, and beryllium concentration.

(h) A description of data and procedures (methods or models) used to design the air sampling network (i.e., number and location of sampling sites).

(i) Air sampling data indicating beryllium concentrations in the vicinity of the stationary source for the 3-year period specified in paragraph (b)(1) of this section. This data shall be presented chronologically and include the beryllium concentration and location of each individual sample taken by the network and the corresponding 30-day average beryllium concentrations.

(2) Within 60 days after receiving such report, the Administrator will notify the owner or operator in writing whether approval is granted or denied. Prior to denying approval to comply with the provisions of paragraph (b) of this section, the Administrator will consult with representatives of the statutory source for which the demonstration report was submitted.

(c) The burning of beryllium and/or beryllium-containing waste, except propellants, is prohibited except in incinerators, emissions from which must comply with the standard.

\subsection{Stack sampling.}

(a) Unless a waiver of emission testing is obtained under 61.13, each owner or operator required to comply with 61.32 (a) shall test emissions from the source according to Method 104 of Appendix B to this part. Method 103 of Appendix B to this part is approved by the Administrator as an alternative method for sources subject to 61.32 (a). The emission test shall be performed- 
(1) Within 90 days of the effective date in the case of an existing source or a new source which has an initial startup date preceding the effective date; or

(2) Within 90 days of startup in the case of a new source which did not have an initial startup date preceding the effective date.

(b) The Administrator shall be notified at least 30 days prior to an emission test so that he may at his option observe the test.

(c) Samples shall be taken over such a period or periods as are necessary to accurately determine the maximum emissions which will occur in any 24-hour period. Where emissions depend upon the relative frequency of operation of different types of processes, operating hours, operating capacities, or other factors, the calculation of maximum 24-hour-period emissions will be based on that combination of factors which is likely to occur during the subject period and which result in the maximum emissions. No changes in the operation shall be made, which would potentially increase emissions above that determined by the most recent source test, until a new emission level has been estimated by calculation and the results reported to the Administrator.

(d) All samples shall be analyzed and beryllium emissions shall be determined within 30 days after the source test. All determinations shall be reported to the Administrator by a registered letter dispatched before the close of the next business day following such determination.

(e) Records of emission test results and other data needed to determine total emissions shall be retained at the source and made available, for inspection by the Administrator, for a minimum of 2 years.

\subsection{Air sampling.}

(a) Stationary sources subject to 61.32 (b) shall locate air sampling sites in accordance with a plan approved by the Administrator. Such sites shall be located in such a manner as is calculated to detect maximum concentrations of beryllium in the ambient air.

(b) All monitoring sites shall be operated continuously except for a reasonable time allowance for instrument maintenance and calibration, for changing filters, or for replacement of equipment needing major repair.

(c) Filters shall be analyzed and concentrations calculated within 30 days after filters are collected. Records of concentrations at all sampling sites and other data needed to determine such concentrations shall be retained at the source and made available, for inspection by the Administrator, for a minimum of 2 years. 
(d) Concentrations measured at all sampling sites shall be reported to the Administrator every 30 days by a registered letter.

(e) The Administrator may at any time require changes in, or expansion of, the sampling network.

\section{A.6 National Emission Standards for Hazardous Air Pollutants for Source Categories, 40 CFR 63, Subpart D}

This regulation governs compliance extensions for early reductions of hazardous air pollutants. 40 CFR 63.74 (f) states:

If lower rates or hours are used to achieve all or part of the emission reduction, any hazardous air pollutant emissions that occur from a compensating increase in rates or hours from the same activity elsewhere within the plant site which contains the source shall be counted in the post-reduction emissions from the source. If emission reductions are achieved by shutting down process equipment and the shutdown equipment is restarted or replaced anywhere within the plant site, any hazardous air pollutant emissions from the restarted or replacement equipment shall be counted in the post-reduction emissions for the source.

This section lists beryllium compounds as high-risk pollutants with a weighting factor of 10 . 


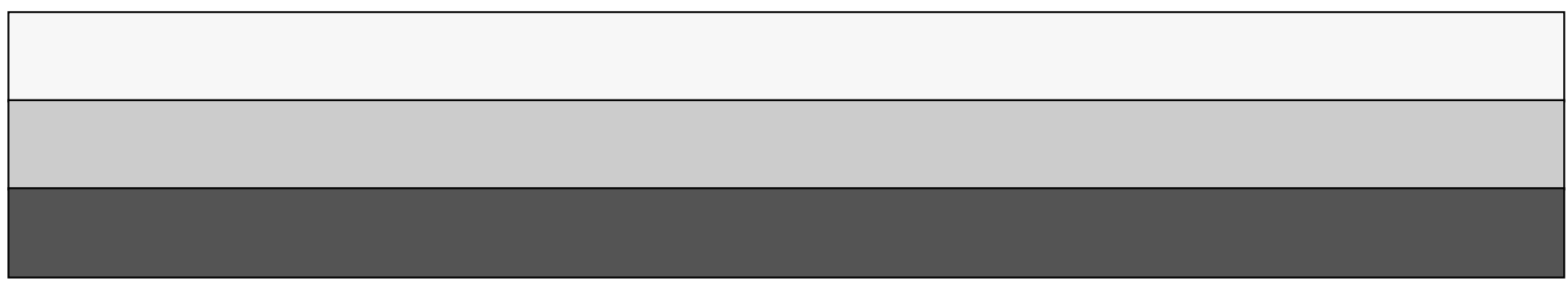

